Prepared in cooperation with the National Park Service

\title{
Hydrologic Data for the Obed River Watershed, Tennessee
}

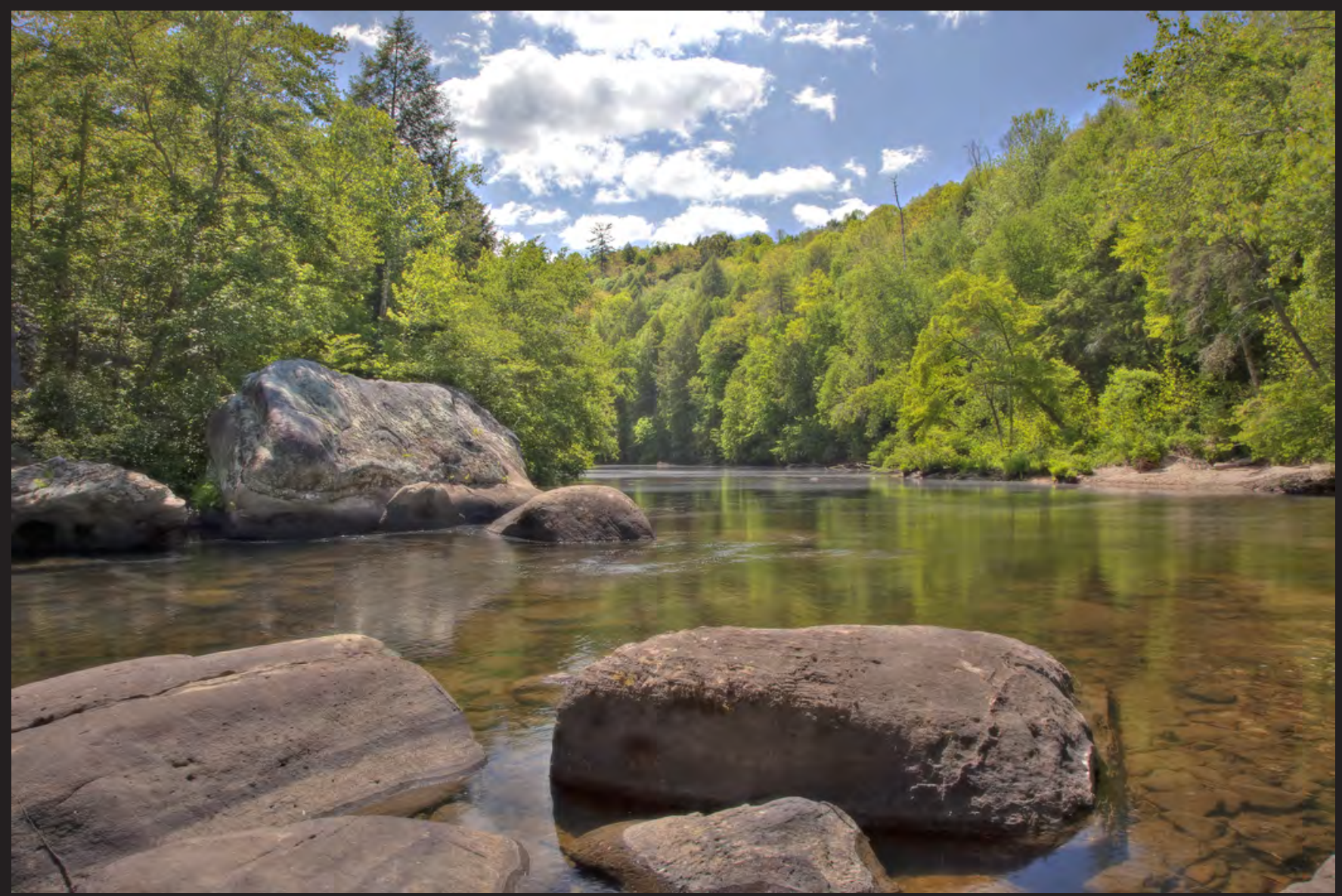

Open-File Report 2014-1102 
Cover photograph. Photo of large boulders in Clear Creek, a tributary to the Obed Wild and Scenic River. Photo taken by T. Wood and used with permission of the National Park Service. 


\section{Hydrologic Data for the Obed River Watershed, Tennessee}

By Rodney R. Knight, William J. Wolfe, and George S. Law

Prepared in cooperation with the National Park Service

Open-File Report 2014-1102 


\title{
U.S. Department of the Interior SALLY JEWELL, Secretary
}

\section{U.S. Geological Survey Suzette M. Kimball, Acting Director}

\author{
U.S. Geological Survey, Reston, Virginia: 2014
}

For more information on the USGS - the Federal source for science about the Earth, its natural and living resources, natural hazards, and the environment, visit http://www.usgs.gov or call 1-888-ASK-USGS.

For an overview of USGS information products, including maps, imagery, and publications, visit http://www.usgs.gov/pubprod

To order this and other USGS information products, visit http://store.usgs.gov

Any use of trade, firm, or product names is for descriptive purposes only and does not imply endorsement by the U.S. Government.

Although this information product, for the most part, is in the public domain, it also may contain copyrighted materials as noted in the text. Permission to reproduce copyrighted items must be secured from the copyright owner.

Suggested citation:

Knight, R.R., Wolfe, W.J., and Law, G.S., 2014, Hydrologic data for the Obed River watershed, Tennessee: U.S. Geological Survey Open-File Report 2014-1102, 24 p., http://dx.doi.org/10.3133/ofr20141102.

ISBN 978-1-4113-3795-4

ISSN 0196-1497 (print)

ISSN 2331-1258 (online) 


\section{Contents}

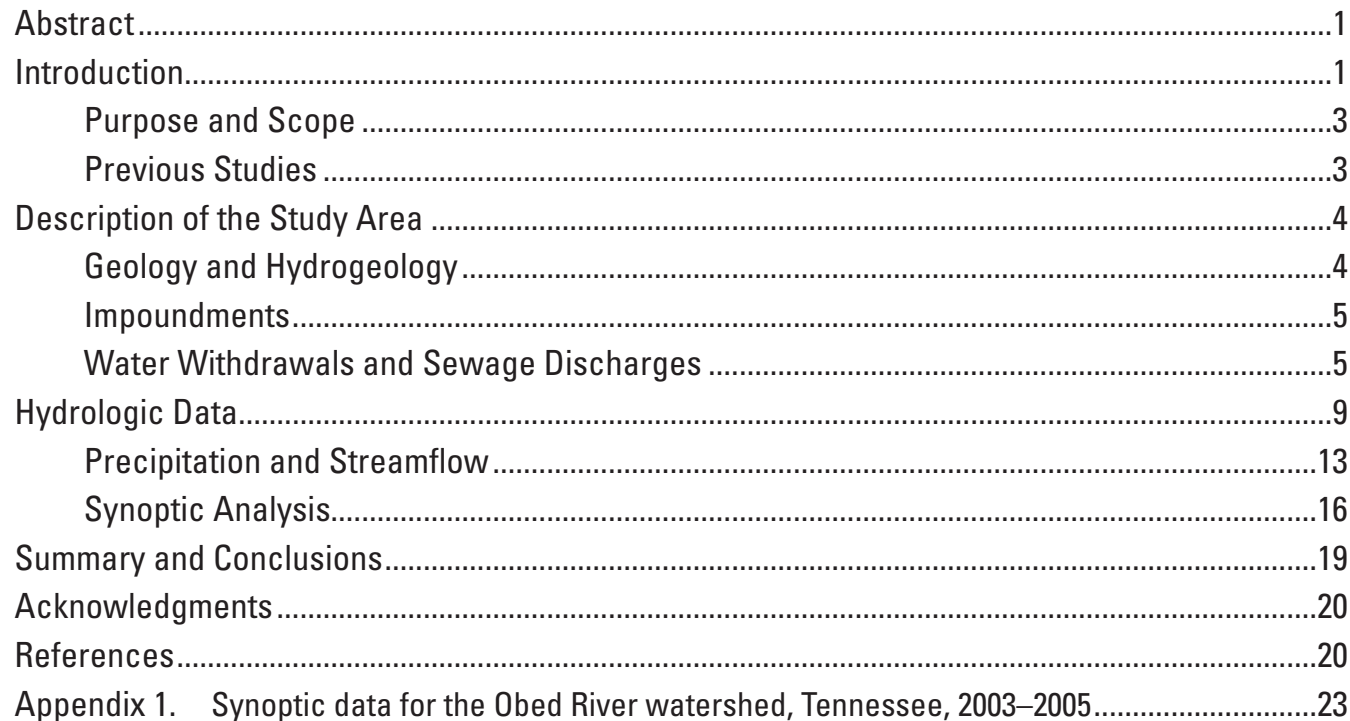

\section{Figures}

1. Map showing location of the rain gage, streamgages, lakes, and other selected features in the Obed River watershed, Tennessee

2. Map showing major structural features of the geology of the Cumberland Plateau overthrust belt, Tennessee ...............................................................................

3. Map showing geology and low-flow sites in the Obed River watershed, Tennessee.

4. Graph showing monthly average discharge from the Crossville wastewater treatment plant as a percentage of monthly average discharge at the Obed River near Lancing streamgage, March 1999 through September 2013, and average wastewater effluent release by water year.

5. Graphs showing annual and cumulative departures from average for annual rainfall at Crossville and annual runoff at the Emory River at Oakdale streamgage, 1930 through 2012.

6. Graph showing annual flow-duration relations for Emory River at Oakdale, Tennessee, 1930 through 2012

7. Graph showing average high- and low-baseflow discharge measurements and the percentages of the Obed River watershed controlled by impoundments, 2003-2005. 


\section{Tables}

1. Population estimates for Cumberland County, Tennessee, 1930-2010 ..............................2

2. Number of impoundments built in the Obed River watershed and Clear Creek and Daddys Creek subwatersheds, by time period. .3

3. Average daily water withdrawals by public water systems in the Cumberland County, Tennessee, area . $\ldots 8$

4. Rain gages and streamgages used in the Obed River watershed study, Tennessee .....10

5. Synoptic-measurement and index sites in the Obed River watershed, Tennessee, 2003-2005

6. Comparison of precipitation and resulting streamflows for two regional droughts in the Obed River Basin, 1952-2009

7. High-baseflow synoptic measurements for the Obed River watershed, Tennessee, 2003-2005

8. Low-baseflow synoptic measurements for the Obed River watershed, Tennessee, 2003-2005

\section{Conversion Factors}

\begin{tabular}{|c|c|c|}
\hline Multiply & By & To obtain \\
\hline \multicolumn{3}{|c|}{ Length } \\
\hline inch (in.) & 2.54 & centimeter $(\mathrm{cm})$ \\
\hline inch (in.) & 25.4 & millimeter (mm) \\
\hline foot (ft) & 0.3048 & meter (m) \\
\hline mile (mi) & 1.609 & kilometer (km) \\
\hline \multicolumn{3}{|c|}{ Area } \\
\hline acre & 4,047 & square meter $\left(\mathrm{m}^{2}\right)$ \\
\hline acre & 0.4047 & hectare (ha) \\
\hline acre & 0.4047 & square hectometer $\left(\mathrm{hm}^{2}\right)$ \\
\hline acre & 0.004047 & square kilometer $\left(\mathrm{km}^{2}\right)$ \\
\hline square mile $\left(\mathrm{mi}^{2}\right)$ & 259.0 & hectare (ha) \\
\hline square mile $\left(\mathrm{mi}^{2}\right)$ & 2.590 & square kilometer $\left(\mathrm{km}^{2}\right)$ \\
\hline \multicolumn{3}{|c|}{ Volume } \\
\hline acre-foot (acre-ft) & 1,233 & cubic meter $\left(\mathrm{m}^{3}\right)$ \\
\hline \multicolumn{3}{|c|}{ Flow rate } \\
\hline cubic foot per second $\left(\mathrm{ft}^{3} / \mathrm{s}\right)$ & 0.02832 & cubic meter per second $\left(\mathrm{m}^{3} / \mathrm{s}\right)$ \\
\hline $\begin{array}{l}\text { cubic foot per second per square mile } \\
{\left[\left(\mathrm{ft}^{3} / \mathrm{s}\right) / \mathrm{mi}^{2}\right]}\end{array}$ & 0.01093 & $\begin{array}{l}\text { cubic meter per second per square } \\
\text { kilometer }\left[\left(\mathrm{m}^{3} / \mathrm{s}\right) / \mathrm{km}^{2}\right]\end{array}$ \\
\hline gallon per minute (gal/min) & 0.06309 & liter per second $(\mathrm{L} / \mathrm{s})$ \\
\hline million gallons per day (Mgal/d) & 0.04381 & cubic meter per second $\left(\mathrm{m}^{3} / \mathrm{s}\right)$ \\
\hline
\end{tabular}


Vertical coordinate information is referenced to the National Geodetic Vertical Datum of 1929 (NGVD 29).

Horizontal coordinate information is referenced to the North American Datum of 1983 (NAD 83).

Elevation, as used in this report, refers to distance above the vertical datum.

Specific conductance is given in microsiemens per centimeter at 25 degrees Celsius

$\left(\mu \mathrm{S} / \mathrm{cm}\right.$ at $\left.25^{\circ} \mathrm{C}\right)$.

\section{Acronyms}
NPS National Park Service
USGS U.S. Geological Survey
WSR Wild and Scenic River
WTTP wastewater treatment plant 



\title{
Hydrologic Data for the Obed River Watershed, Tennessee
}

\author{
By Rodney R. Knight, William J. Wolfe, and George S. Law
}

\section{Abstract}

The Obed River watershed drains a 520-square-mile area of the Cumberland Plateau physiographic region in the Tennessee River basin. The watershed is underlain by conglomerate, sandstone, and shale of Pennsylvanian age, which overlie Mississippian-age limestone. The larger creeks and rivers of the Obed River system have eroded gorges through the conglomerate and sandstone into the deeper shale. The largest gorges are up to 400 feet deep and are protected by the Wild and Scenic Rivers Act as part of the Obed Wild and Scenic River, which is managed by the National Park Service.

The growing communities of Crossville and $\mathrm{Crab}$ Orchard, Tennessee, are located upstream of the gorge areas of the Obed River watershed. The cities used about 5.8 million gallons of water per day for drinking water in 2010 from Lake Holiday and Stone Lake in the Obed River watershed and Meadow Park Lake in the Caney Fork River watershed. The city of Crossville operates a wastewater treatment plant that releases an annual average of about 2.2 million gallons per day of treated effluent to the Obed River, representing as much as 10 to 40 percent of the monthly average streamflow of the Obed River near Lancing about 35 miles downstream, during summer and fall. During the past 50 years (1960-2010), several dozen tributary impoundments and more than 2,000 small farm ponds have been constructed in the Obed River watershed. Synoptic streamflow measurements indicate a tendency towards dampened high flows and slightly increased low flows as the percentage of basin area controlled by impoundments increases.

\section{Introduction}

The Obed Wild and Scenic River (WSR), established in 1976 under the Wild and Scenic Rivers Act of 1968 (82 Statute 906, Public Law 90-542) and managed by the National Park Service (NPS), occupies about 14 square miles $\left(\mathrm{mi}^{2}\right)$ of rugged river gorge cut into the Cumberland Plateau of East Tennessee (fig. 1). The Obed WSR composes only about 3 percent of the drainage area $\left(520 \mathrm{mi}^{2}\right)$ of the Obed River at its confluence with the Emory River. The basin upstream of the WSR includes the rapidly growing communities of Crossville, Crab Orchard, and Fairfield Glade, Tennessee, all of which withdraw water from and release treated wastewater to the Obed River or its tributaries (fig. 1). After moderate population growth in the 1930s and 1940s, population stabilized at around 19,000 in the 1950s and 1960s (table 1). Beginning in the 1970 s, the county entered a period of sustained population growth. Population growth has been accompanied by construction of more than 2,000 impoundments in the Obed River headwaters for water supply, recreation, livestock watering, and irrigation (table 2; Forester and others, 1998). Water withdrawals, wastewater releases, impoundments, and other human activities have potential to change the flow regime of the Obed River, possibly affecting the ecological, recreational, scenic, and other values and functions that helped justify the river's protection under the Wild and Scenic Rivers Act.

The Wild and Scenic Rivers Act requires the NPS to preserve rivers of the WSR system in "free-flowing condition to protect the water quality of such rivers and to fulfill other vital national conservation purposes." To meet this responsibility, the NPS must evaluate conditions or factors with potential to alter the natural flow of streams in the WSR system. The legal responsibility of the NPS to mitigate threats to the natural flow regime of the Obed WSR requires an evaluation of the hydrologic effects of human activities in the Obed River watershed. In 1999, the U.S. Geological Survey (USGS) began a cooperative effort with the NPS to assemble historical datasets and collect hydrologic data in the Obed River and its tributaries to support an assessment of the hydrologic effects of human activities in the basin. 


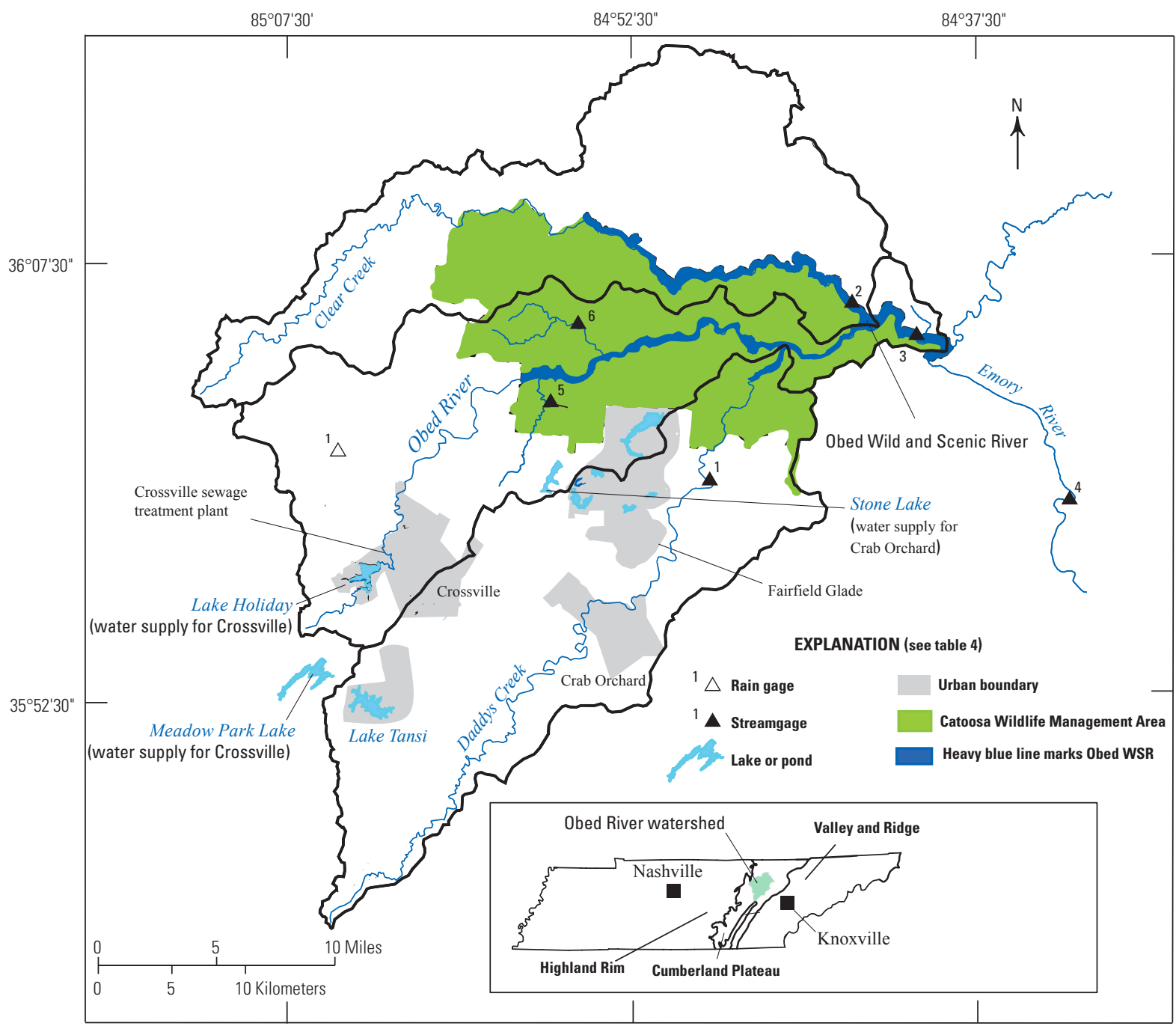

Base from U.S. Geological Survey topographic quadrangles, 1:24,000

Lambert Conformal Conic projection

Standard parallels $35^{\circ} 15^{\prime} \mathrm{N}$ and $36^{\circ} 25^{\prime} \mathrm{N}$

central meridian $86^{\circ} \mathrm{W}$

Figure 1. Location of the rain gage (operated by the National Weather Service), streamgages, lakes, and other selected features in the Obed River watershed, Tennessee.

Table 1. Population estimates for Cumberland County, Tennessee, 1930-2010.

[n/a, not available; \%, percent; population estimates from Center for Business and Economic Research, 2014]

\begin{tabular}{lcccccrrrr}
\hline & $\mathbf{1 9 3 0}$ & $\mathbf{1 9 4 0}$ & $\mathbf{1 9 5 0}$ & $\mathbf{1 9 6 0}$ & $\mathbf{1 9 7 0}$ & $\mathbf{1 9 8 0}$ & $\mathbf{1 9 9 0}$ & $\mathbf{2 0 0 0}$ & $\mathbf{2 0 1 0}$ \\
\hline $\begin{array}{l}\text { population } \\
\begin{array}{c}\text { net change by } \\
\text { decade }\end{array}\end{array}$ & 11,440 & 15,592 & 18,877 & 19,135 & 20,733 & 28,676 & 34,736 & 46,802 & 54,251 \\
$\begin{array}{c}\text { percent change } \\
\text { by decade }\end{array}$ & $\mathrm{n} / \mathrm{a}$ & 4,152 & 4,152 & 258 & 1,598 & 7,943 & 6,060 & 12,066 & 7,449 \\
\hline
\end{tabular}


Table 2. Number of impoundments built in the Obed River watershed and Clear Creek and Daddys Creek subwatersheds, by time period.

[mi², square miles; -, not available]

\begin{tabular}{|c|c|c|c|c|c|}
\hline \multirow[b]{2}{*}{ Watershed } & \multirow[b]{2}{*}{ Drainage area, $\mathrm{mi}^{2}$} & \multirow[b]{2}{*}{ Time period ${ }^{\mathrm{a}}$} & \multicolumn{3}{|c|}{ Total at end of time period } \\
\hline & & & $\begin{array}{l}\text { Cumulative number of } \\
\text { impoundments }\end{array}$ & $\begin{array}{l}\text { Surface area of im- } \\
\text { poundments, } \mathrm{mi}^{2}\end{array}$ & $\begin{array}{c}\text { Drainage area } \\
\text { controlled by major } \\
\text { impoundments, mi }\end{array}$ \\
\hline \multirow[t]{4}{*}{ Obed River } & 172 & 1943-1975 & 215 & 0.47 & - \\
\hline & & 1976-1987 & 438 & 1.17 & - \\
\hline & & 1988-1997 & 921 & 2.28 & - \\
\hline & & 1998-2002 & 929 & 2.28 & 28.3 \\
\hline \multirow[t]{4}{*}{ Clear Creek } & 173 & $1943-1975$ & 133 & 0.15 & - \\
\hline & & 1976-1987 & 380 & 0.54 & - \\
\hline & & 1988-1997 & 672 & 0.73 & - \\
\hline & & 1998-2002 & 695 & 0.75 & 8.64 \\
\hline \multirow[t]{4}{*}{ Daddys Creek } & 175 & $1943-1975$ & 40 & 0.19 & - \\
\hline & & 1976-1987 & 318 & 1.59 & - \\
\hline & & 1988-1997 & 830 & 2.43 & - \\
\hline & & 1998-2002 & 830 & 2.43 & 32 \\
\hline \multirow[t]{4}{*}{ Total for study area } & 520 & $1943-1975$ & 388 & 0.82 & - \\
\hline & & 1976-1987 & 1,136 & 3.3 & - \\
\hline & & 1988-1997 & 2,423 & 5.44 & - \\
\hline & & 1998-2002 & 2,454 & 5.46 & 68.9 \\
\hline
\end{tabular}

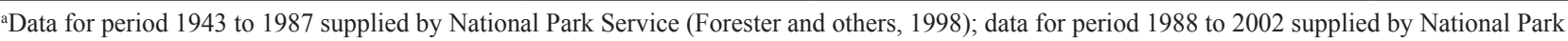
Service (Jacob Morgan, National Park Service, written commun., 2007).

\section{Purpose and Scope}

This report presents the findings of USGS hydrologic studies conducted in cooperation with the National Park Service in the Obed River watershed during 1999 through 2005. The report includes analysis of historical and contemporary streamflow and precipitation records from the Obed River watershed and a qualitative assessment of the influence of increased human alteration and climate on the flow regime of the Obed WSR.

The USGS conducts research to improve the understanding of the water resources of the Nation. A key science direction for the USGS Tennessee Water Science Center is the evaluation of changes to instream conditions and aquatic ecosystem health resulting from land-cover change, climate change, and management or mitigation measures. The results from this investigation will provide additional data and information to help meet that science goal. The investigation also provides information about the effects of the geology, climate, and human activities on the streamflow and water cycle of the area that will aid the USGS in advancing the understanding of the processes that determine water availability (Evenson and others, 2013).

\section{Previous Studies}

The first detailed studies of the Obed River watershed were conducted in the 1890 s and early 1900 s by the USGS and focused on producing general geologic folios (Keith, 1897) and topographic maps (U.S. Geological Survey, 1913) of the region. Geology and mineral resources of this part of Tennessee were studied by Stearns (1954), Luther (1959), Johnson and Luther (1972), and Wilson and others (1956). Wilson (1965) reported on the groundwater resources and hydrogeology of Cumberland County, Tenn., at a time when most of the population of the county obtained their water supply from domestic wells. Wilson (1965) revised the geologic naming conventions previously established by Stearns (1954) and Wilson and others (1956); the geologic names used in this report follow Wilson (1965) and conform to current usage by the USGS and the Tennessee Division of Geology. Brahana and others (1986) developed a preliminary description and delineation of the aquifers of the Cumberland Plateau.

Early studies of surface-water hydrology in the study area included general waterway surveys (U.S. Army Corps of Engineers, 1930; Tennessee Valley Authority, 1954, 1970) and studies of floods (Tennessee Valley Authority, 1960) and 
droughts (Tennessee Valley Authority, 1958). Many of these studies were conducted in the context of proposed impoundment of the Obed River, which was under consideration until about 1970 (National Park Service, 1993). More recently, the U.S. Army Corps of Engineers (1998) published a study of the Obed River watershed that includes a reconnaissance of water-supply sources of Cumberland County and assessment of water-supply alternatives for the county.

Following establishment of the Obed WSR in 1976, the focus of hydrologic studies shifted to the ecological implications of streamflow and water quality in the WSR (National Park Service, 1999). Initial reconnaissance and feasibility reports for the Obed WSR (Bureau of Outdoor Recreation, 1976a, b; National Park Service, 1978) included general discussions of hydrologic conditions in the proposed WSR and its drainage basin (J.C. Hughes, National Park Service, written commun., 2007). Reports by Minear and Tschantz (1976), Gaydos and others (1982), and Gottfried and others (1984) explored linkages between strip mining of coal and the aquatic environment of the Cumberland Plateau. Other studies documented the benthic fauna of streams on or adjacent to the Cumberland Plateau in Tennessee (Pennington and Estes, 1980; Gore and others, 1982; Bradfield, 1986a, b) and the proliferation of small dams and reservoirs constructed on creeks and rivers in Tennessee (Goodwin, 1981).

Recent studies have emphasized specific management questions or furthered the understanding of ecology and hydrology in the WSR and surrounding area. Forester and others (1998) produced a water-resources management plan for the Obed WSR describing decision-making and management processes for the conservation and management of water resources in the Obed WSR. The water-resources management plan is an extension of the general management plan for the park (National Park Service, 1995). In 2004, researchers from the University of Tennessee at Chattanooga developed a digital record of surface-water impoundments in the Obed River watershed (National Park Service, 2004). The impoundments range from farm ponds to small lakes having surface areas of several hundred acres. Arnwine and others (2006) reported on stream monitoring below small impoundments throughout Tennessee, including water-quality analyses for streams below several of the larger impoundments in the Obed River watershed. Recent academic theses from Tennessee Technological University examined current distribution and seasonal habitat use of the threatened spotfin chub (Russ, 2006) and benthic macroinvertebrate communities (Goodfred, 2006) within the Emory River watershed. Wolfe and others (2007) described the physical characteristics and spatial distribution of the Obed WSR alluvial bars, the role of hydrology in creating and maintaining them, patterns of plant distribution, and potential threats to alluvial-bar plant communities.

\section{Description of the Study Area}

The dominant landscape of the Obed River watershed is a gently rolling plateau covered by farms, pastures, and forest. Many of the forests are second growth, having been clearcut in the early 1900s. The land has also been affected by localized strip-mining of coal prior to the 1970s (Johnson and Luther, 1972). The elevation of the plateau ranges generally between 1,200 and 2,000 feet (ft) above the National Geodetic Vertical Datum of 1929 (NGVD 29), with the Crab Orchard Mountains about 3,000 ft above NGVD 29 (Griffith and others, 1997). The Obed River watershed is about $1,000 \mathrm{ft}$ higher in elevation than the Highland Rim physiographic region to the west and the Valley and Ridge physiographic region to the east. The Obed River is a tributary to the Emory River, and its $520-\mathrm{mi}^{2}$ basin composes 60 percent of the Emory River watershed at their confluence.

The Obed River watershed lies entirely within the Cumberland Plateau physiographic region (Griffith and others, 1997). The streams and rivers of this region are characterized by rapid runoff following storms and by low flow or no flow during the drier months in late summer and fall. Streams with drainage areas less than approximately $1 \mathrm{mi}^{2}$ are generally ephemeral in the study area, flowing only in direct response to local rainfall (Law and others, 2009). Streams in the study area with drainage areas between 1 and $100 \mathrm{mi}^{2}$ have flow regimes that range from ephemeral-intermittent to intermittent-perennial, commonly experiencing seasonal periods with little or no flow, even when some dry-season pools are maintained. Streams with drainage areas greater than $100 \mathrm{mi}^{2}$ generally are perennial and maintain flow throughout the year. The larger streams and rivers of the Obed River watershed have formed deeply incised gorges cut through sandstone and conglomerate layers down to and, in places, through underlying shale layers (Stearns, 1954; Wilson and others, 1956; Wilson, 1965; Milici, 1968).

\section{Geology and Hydrogeology}

Geologic strata in the study area generally are level or dip gently to the southeast (Stearns, 1954) (fig. 2). Local deformation due to thrust faulting and cross faulting (fig. 2) occurs primarily in strata that overlie the Mississippian-age limestone of the area (fig. 3). Additionally, several major geologic features, such as the Sequatchie Valley anticline, $\mathrm{Crab}$ Orchard Mountains anticline, and the Cumberland Plateau overthrust belt, interrupt the generally horizontal geologic structure (fig. 2; Stearns, 1954; Wilson and others, 1956; Milici, 1968). The overthrust belt is related to the faults in the underlying Mississippian and older formations (fig. 3), which are exposed primarily to the east and south in the Valley and Ridge physiographic region and Sequatchie Valley. Exposures of Mississippian-age limestone within the study area are found mainly at Crab Orchard Cove (fig. 3; Stearns, 1954; Wilson and others, 1956; Milici, 1968). 
The Obed River watershed is underlain mainly by sandstones, siltstones, conglomerates, and shales of Pennsylvanian age with minor coal seams (fig. 3; Stearns, 1954; Wilson and others, 1956; Wilson, 1965). Major geologic units in the study area include the Crooked Fork Group, Rockcastle Conglomerate of the Crab Orchard Group, and the Vandever Formation and lower Crab Orchard Group. The Crooked Fork Group includes four units - a lower shale unit, the Crossville Sandstone member, an upper shale unit, and an upper sandstone unit. Throughout most of the study area, the upper sandstone and shale layers have been worn away by weathering and erosion. The lower shale unit and Crossville Sandstone have average thicknesses of about $50 \mathrm{ft}$ and $100 \mathrm{ft}$, respectively. The Crossville Sandstone is the only member of the Crooked Fork Group that has substantial water-bearing capacity. The Crossville Sandstone, however, has low hydraulic conductivity, and yields of 5 to 10 gallons per minute (gal $/ \mathrm{min}$ ) are typical (Wilson, 1965).

The shaley Vandever Formation (fig. 3) transmits little groundwater flow, and few, if any, water-supply wells have been completed in this unit (Wilson, 1965). Exposed contacts between the Vandever Formation and the Rockcastle Conglomerate are sites of seeps and springs throughout the Obed River watershed. Seeps occurring on this geologic contact provide baseflow to perennial streams during dry periods (M.W. Bradley, U.S. Geological Survey, written commun., 2007). Some streams have cut through the Vandever Formation into the underlying Bonair sandstones in the Gizzard Group (Stearns, 1954; Wilson, 1965) and are likely to lose streamflow, especially during baseflow conditions.

The Rockcastle Conglomerate, positioned above the Vandever Formation and below the Crooked Fork Group (fig. 3), is the primary water-bearing geologic unit in the Obed River watershed. Most of the domestic wells in the watershed are completed in this unit, which has an average thickness of $150 \mathrm{ft}$ (Stearns, 1954; Wilson, 1965). Groundwater occupies fracture systems within the massive cross-bedded sandstone, which is the principal component of the formation, and along bedding planes separated by thin stringers of shale (Wilson, 1965). Wells completed in the Rockcastle Conglomerate are mostly artesian, with water levels rising up to $100 \mathrm{ft}$ above the water-bearing fracture systems. Reported yields of wells in the Rockcastle Conglomerate are up to $35 \mathrm{gal} / \mathrm{min}$ and average about $8 \mathrm{gal} / \mathrm{min}$ (Wilson, 1965).

\section{Impoundments}

Numerous small water-supply, recreational, and farm ponds have been constructed in headwater tributaries of the Obed River watershed and are collectively referred to as impoundments in this report. Recently, concern has risen over the potential effects of these impoundments on the hydrologic environment of the Obed WSR (Pringle, 2000). The water-resources management plan for the Obed WSR (Forester and others, 1998) notes that stream impoundment generally reduces natural physical and biological variability and promotes conditions of constancy within a stream system. In 1975, there were 388 impoundments in the Obed River watershed (Forester and others, 1998). By 1997, the number of impoundments had increased to 2,423 (table 2). After 1998 , the rate of new impoundment construction slowed, probably reflecting a combination of economic conditions, increasing scarcity of suitable sites, greater public awareness of permitting requirements, and concerns about possible adverse environmental effects (R.D. Baker, Tennessee Department of Environment and Conservation, written commun., 2008). As of March 2002, impoundments in the Obed River watershed had a combined water-surface area of $5.46 \mathrm{mi}^{2}$ (table 2).

Aerial photographs and digital elevation models indicate that about 13 percent $\left(69 \mathrm{mi}^{2}\right)$ of the Obed River watershed drains to impoundments, primarily in the headwaters (Jacob Morgan, National Park Service, written commun., 2007). About 80 percent of the impoundments are for farm and private recreational purposes, with individual water-surface areas generally less than 1 acre and a combined water-surface area ranging from 1 to $1.5 \mathrm{mi}^{2}$, depending on weather conditions. These small ponds receive runoff from a combined watershed area of about $38 \mathrm{mi}^{2}$. About 15 percent of impoundments in the Obed River watershed have surface areas of 1 to 10 acres, with a combined surface area ranging from 1.5 to $2.5 \mathrm{mi}^{2}$, depending on weather conditions, and combined drainage areas represent 10 percent of the Obed River watershed (roughly $52 \mathrm{mi}^{2}$ ).

Impoundments with a surface area greater than 10 acres compose about 2 percent of the impoundments in the Obed River watershed. The largest of these impoundments is Lake Tansi near Crossville (fig. 1), which has a designed surface area of 425 acres $\left(0.66 \mathrm{mi}^{2}\right)$ and a design volume of 12,300 acre-feet (acre-ft; Lyle Bentley, Tennessee Department of Environment and Conservation, written commun., 2007). Larger impoundments in the Obed River watershed have a combined surface area ranging from 2.5 to $4 \mathrm{mi}^{2}$, depending on weather conditions, and receive runoff from about $76 \mathrm{mi}^{2}$. Many tributary watersheds have multiple impoundments.

\section{Water Withdrawals and Sewage Discharges}

The cities of Crossville and Crab Orchard collect and distribute drinking water for much of Cumberland County (Hutson and Morris, 1992; Hutson, 1999; Webbers, 2003; Bohac and McCall, 2008; J.L. Kerley, City of Crossville, written commun., 2010; W.L. Muirhead, Tennessee Department of Environment and Conservation, written commun., 2010). The sources of this drinking water are Meadow Park Lake, Lake Holiday, and Stone Lake in the headwaters of the Obed River and Caney Fork watersheds (fig. 1). Groundwater sources are not being used for public drinking water by municipal water systems in this area.

In 2010, Crossville and Crab Orchard withdrew, treated, and distributed 4.2 million gallons per day (Mgal/d) and 


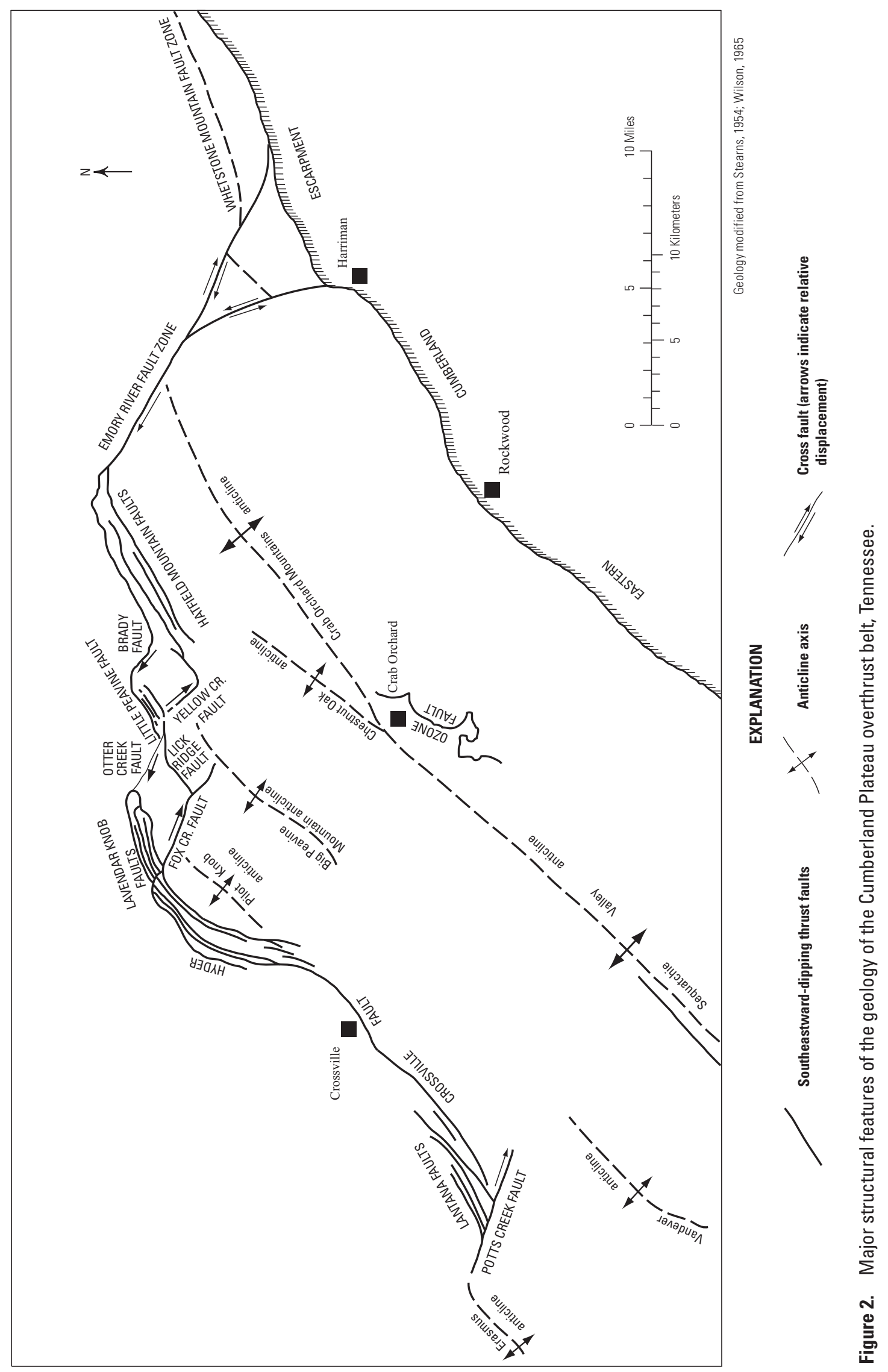




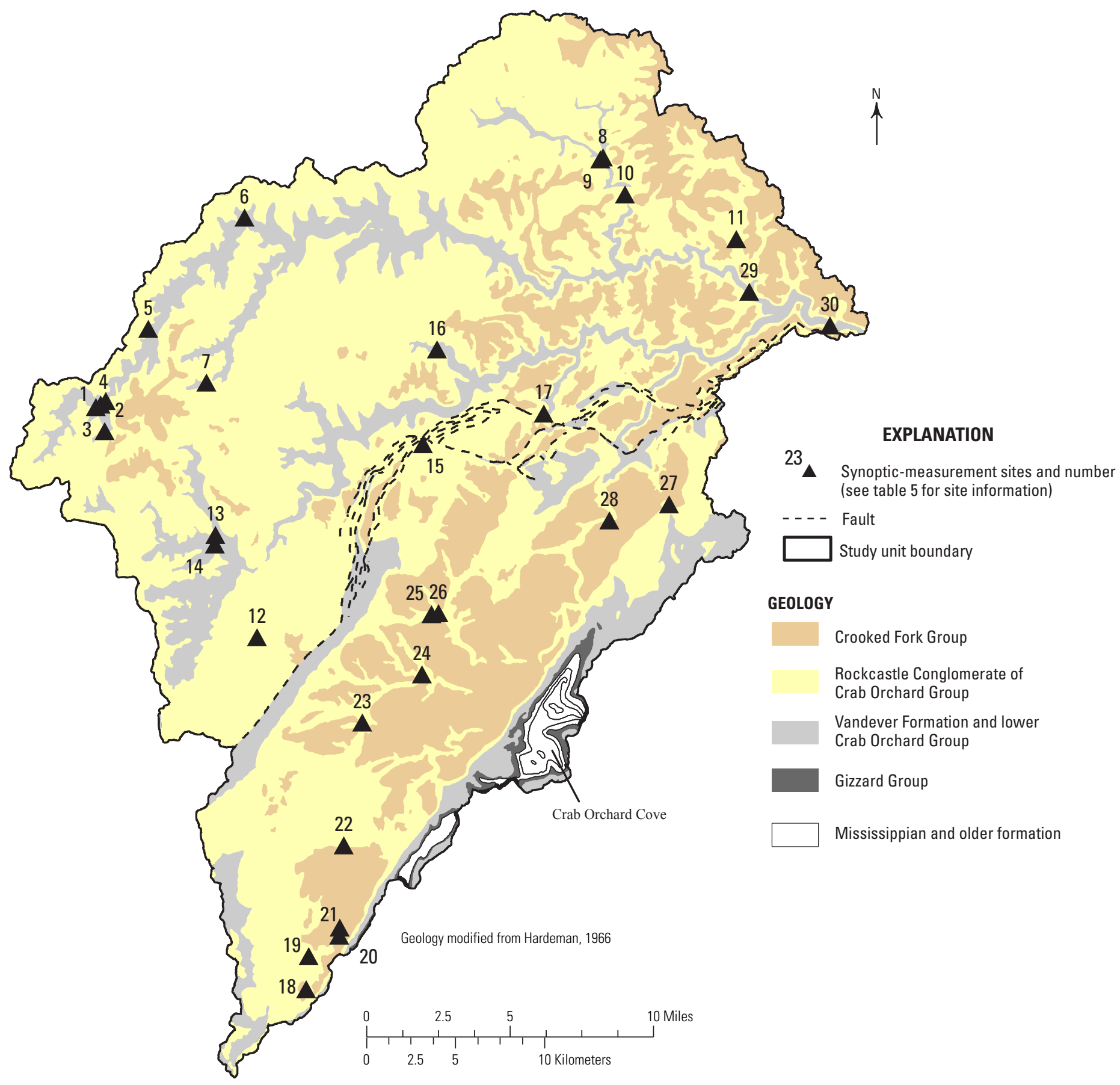

Figure 3. Geology and low-flow sites in the Obed River watershed, Tennessee. 
1.6 Mgal/d of drinking water, respectively (table 3 ). As of 2010, the combined capacity of these drinking-water systems was about $8 \mathrm{Mgal} / \mathrm{d}$ (Robinson and Brooks, 2010). Analyses by the U.S. Army Corps of Engineers (1998) indicate that future water-supply needs for Crossville, Crab Orchard, and Cumberland County will exceed $10 \mathrm{Mgal} / \mathrm{d}$ by the year 2020 .

The city of Crossville wastewater treatment plant (WWTP) is the only centralized wastewater system in the study area. The Crossville WWTP is located on the Obed River about 1 mile (mi) downstream of Lake Holiday and about 14 mi upstream of the Obed WSR boundary (fig. 1). In 2010, the Crossville WWTP discharged an average of $2.08 \mathrm{Mgal} / \mathrm{d}$ of treated effluent to the Obed River (R. Baker, Tennessee Department of Environment and Conservation, written commun., 2010). As of 2005, eight decentralized wastewater-treatment systems were applying a total of about $0.13 \mathrm{Mgal} / \mathrm{d}$ of treated effluent to land in the headwaters of the Obed River watershed. Five of these systems use spray irrigation, and three use drip irrigation.

About 52 percent of the public drinking water produced by Crossville is returned to the Obed River as treated effluent, which can account for a considerable proportion of flow in the river. During extended dry periods, filter backwash from the drinking-water plant, effluent discharged from Crossville WWTP, and limited groundwater discharge are the only flows into the Obed River at Crossville. Lake Holiday does not provide a guaranteed minimum flow for dilution of effluent from the Crossville WWTP (J.L. Kerley, City of Crossville, written commun., 2010). The most direct effect of WWTP effluent on flow conditions in the Obed WSR appears to occur during low-baseflow conditions from July through October of a typical year. During these periods, effluent released from the Crossville WWTP can constitute about 10 to more than 40 percent of the observed streamflow of the Obed River near Lancing, TN (03539800) (fig. 4A). The basin area at the Obed River near Lancing is about 40 times larger than the basin area at the location of the effluent discharge, indicating that effluent releases by the Crossville WWTP are greatly influencing downstream flow conditions. The effect of effluent releases on the low-flow variability of the Obed WSR has not been thoroughly evaluated; however, the wastewater discharge most likely increases the lowest flows expected along much of the

Table 3. Average daily water withdrawals by public water systems in the Cumberland County, Tennessee, area.

[See fig. 1 for general location of water-supply lakes in the study area; $\mathrm{ft}^{3} / \mathrm{s}$, cubic foot per second; Mgal/d, million gallons per day; - , prior to water withdrawal]

\begin{tabular}{|c|c|c|c|c|}
\hline \multirow{2}{*}{ Public water system } & \multirow{2}{*}{ Location of system intake } & \multirow{2}{*}{ Calendar year } & \multicolumn{2}{|c|}{ Average daily usage } \\
\hline & & & $\mathrm{ft}^{3} / \mathrm{s}$ & $\mathrm{Mgal} / \mathrm{d}$ \\
\hline \multicolumn{5}{|c|}{ Obed River watershed } \\
\hline \multirow[t]{5}{*}{ Crab Orchard } & $\begin{array}{l}\text { Stone Lake on Otter } \\
\text { Creek }\end{array}$ & $1988^{a}$ & - & - \\
\hline & & $1995^{b}$ & 1.38 & 0.89 \\
\hline & & $2000^{c}$ & 2.18 & 1.41 \\
\hline & & $2005^{d}$ & 2.40 & 1.55 \\
\hline & & $2010^{\mathrm{e}}$ & 2.48 & 1.6 \\
\hline \multirow[t]{5}{*}{ Crossville } & $\begin{array}{l}\text { Lake Holiday on Obed } \\
\text { River }\end{array}$ & $1988^{a}$ & 3.95 & 2.55 \\
\hline & & $1995^{b}$ & 2.96 & 1.91 \\
\hline & & $2000^{c}$ & 2.85 & 1.84 \\
\hline & & $2005^{d}$ & 2.01 & 1.30 \\
\hline & & $2010^{\mathrm{e}}$ & 1.81 & 1.17 \\
\hline \multicolumn{5}{|c|}{ Caney Fork watershed } \\
\hline \multirow[t]{5}{*}{ Crossville } & $\begin{array}{l}\text { Meadow Park Lake on } \\
\text { Meadow Creek }\end{array}$ & $1988^{a}$ & 0.71 & 0.46 \\
\hline & & $1995^{\mathrm{b}}$ & 1.89 & 1.22 \\
\hline & & $2000^{c}$ & 1.69 & 1.09 \\
\hline & & $2005^{d}$ & 4.00 & 2.59 \\
\hline & & $2010^{\mathrm{e}}$ & 4.75 & 3.07 \\
\hline
\end{tabular}

${ }^{\mathrm{a}}$ Hutson and Morris, 1992; ${ }^{\mathrm{b}}$ Hutson, 1999; ${ }^{\mathrm{c}}$ Webbers, 2003; ${ }^{\mathrm{d}}$ Robinson and Brooks, 2010; ${ }^{\mathrm{e}}$ Tennessee Department of Environment and Conservation, Division of Water Supply, open-file records, provisional data, 2011; ${ }^{\mathrm{f}}$ interbasin transfer from Cumberland River Basin to Tennessee River Basin. 
Obed River in any given year and decreases the low-flow variability. This brief analysis provides a conservative estimate for the effect of wastewater effluent on the flow of the Obed River and does not account for return flow from residential septic systems (fig. 4B).

\section{Hydrologic Data}

Data presented in this report include long-term streamflow and rainfall records, monthly average wastewater return flows, and synoptic discharge measurements. Historical and contemporary data from five streamgages in the Obed River watershed and one on the Emory River (table 4; fig. 1) were used to examine long-term changes in streamflow in the study area. Published rainfall records from the National Weather Service Crossville Experiment Station were used to study rainfall trends.

Synoptic discharge measurements were made at 27 stream sites on seven occasions (table 5; appendix 1). A typical range of high- to low-baseflow conditions was measured and compared with watershed characteristics and streamflow at the long-term gaging stations to assess anthropogenic effects. Watershed characteristics, including drainage area, geology, and watershed area controlled by impoundments upstream of the measurement sites, are listed for each site in table 5.

Synoptic-measurement sites were selected to represent the two dominant geologic formations underlying the Obed River watershed: the Rockcastle Conglomerate-Crooked Fork Group and the Vandever Formation (table 5). The majority
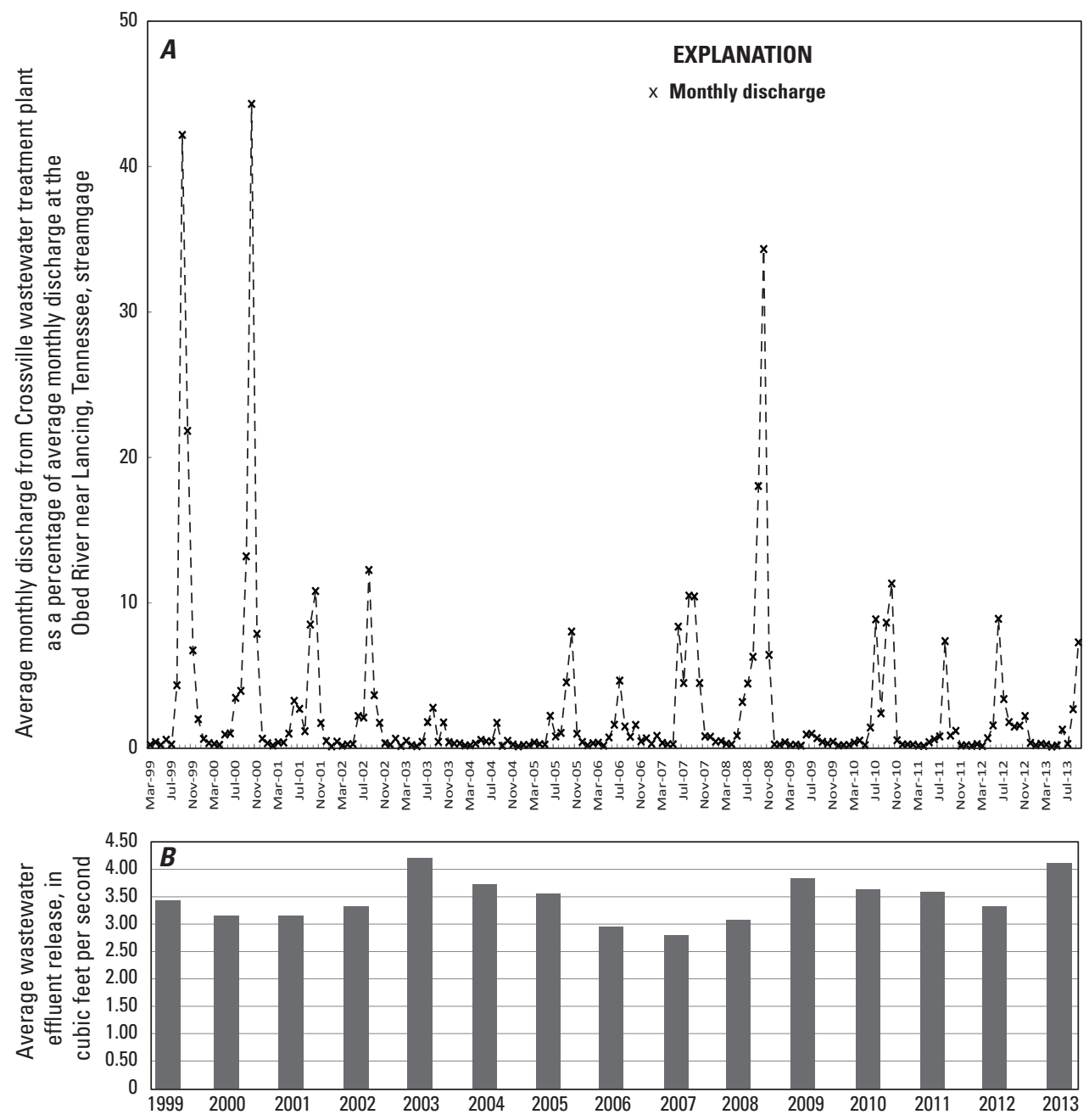

Figure 4. A, Monthly average discharge from the Crossville wastewater treatment plant as a percentage of monthly average discharge at the Obed River near Lancing streamgage, March 1999 through September 2013 and B, average wastewater effluent release by water year. 
Table 4. Rain gages and streamgages used in the Obed River watershed study, Tennessee.

$\left[\mathrm{mi}^{2}\right.$, square miles; -, not applicable]

\begin{tabular}{|c|c|c|c|c|c|c|}
\hline $\begin{array}{l}\text { Site no. } \\
\text { (fig. 1) }\end{array}$ & $\begin{array}{l}\text { Station } \\
\text { number }\end{array}$ & $\begin{array}{l}\text { Station name } \\
\text { (short name) }\end{array}$ & $\begin{array}{c}\text { Latitude, in } \\
\text { degrees, minutes, } \\
\text { seconds }\end{array}$ & $\begin{array}{c}\text { Longitude, in } \\
\text { degrees, minutes, } \\
\text { seconds }\end{array}$ & $\begin{array}{l}\text { Drainage area, } \\
\text { in } \mathrm{mi}^{2}\end{array}$ & Period of record \\
\hline \multicolumn{7}{|c|}{ Rain gage } \\
\hline 1 & COOP:402202 & $\begin{array}{l}\text { Crossville Experiment } \\
\text { Station }\end{array}$ & $36^{\circ} 01^{\prime} 00^{\prime \prime}$ & $85^{\circ} 08^{\prime} 00^{\prime \prime}$ & - & 1912-present \\
\hline \multicolumn{7}{|c|}{ Streamgages } \\
\hline 1 & 03539600 & $\begin{array}{l}\text { Daddys Creek near } \\
\text { Hebbertsburg }\end{array}$ & $35^{\circ} 59^{\prime} 51^{\prime \prime}$ & $84^{\circ} 49^{\prime} 21^{\prime \prime}$ & 139 & $\begin{array}{l}\text { 1957-68, } \\
\text { 99-present }\end{array}$ \\
\hline 2 & 03539778 & $\begin{array}{l}\text { Clear Creek at Lilly } \\
\text { Bridge }\end{array}$ & $36^{\circ} 06^{\prime} 11^{\prime \prime}$ & $84^{\circ} 43^{\prime} 06^{\prime \prime}$ & 170 & 1997-present \\
\hline 3 & 03539800 & $\begin{array}{l}\text { Obed River near } \\
\text { Lancing }\end{array}$ & $36^{\circ} 04^{\prime} 53^{\prime \prime}$ & $84^{\circ} 40^{\prime} 13^{\prime \prime}$ & 518 & $\begin{array}{l}\text { 1957-68, 73-87, } \\
\text { 99-present }\end{array}$ \\
\hline 4 & 03540500 & $\begin{array}{c}\text { Emory River at } \\
\text { Oakdale }\end{array}$ & $35^{\circ} 58^{\prime} 59^{\prime \prime}$ & $84^{\circ} 33^{\prime} 29^{\prime \prime}$ & 764 & 1927-present \\
\hline 5 & 03538845 & $\begin{array}{l}\text { Fox Creek near } \\
\text { Lavendar Knob }\end{array}$ & $36^{\circ} 02^{\prime} 47^{\prime \prime}$ & $84^{\circ} 56^{\prime} 00^{\prime \prime}$ & 7.38 & 2001-2003 \\
\hline 6 & 03538865 & $\begin{array}{l}\text { Elmore Creek near } \\
\text { Genesis }\end{array}$ & $36^{\circ} 05^{\prime} 34^{\prime \prime}$ & $84^{\circ} 55^{\prime} 03^{\prime \prime}$ & 7.82 & 2001-2003 \\
\hline
\end{tabular}

Table 5. Synoptic-measurement and index sites in the Obed River watershed, Tennessee, 2003-2005.

[mi², square miles; Pcf, Crooked Fork Group; Pr, Rockcastle Conglomerate; Pv, Vandever Formation]

\begin{tabular}{|c|c|c|c|c|c|c|c|c|c|c|c|}
\hline \multirow{2}{*}{$\begin{array}{l}\text { USGS } \\
\text { station } \\
\text { number }\end{array}$} & \multirow{2}{*}{$\begin{array}{l}\text { Site name } \\
\text { (number on } \\
\text { figure } 3 \text { ) }\end{array}$} & \multirow{2}{*}{ Latitude } & \multirow{2}{*}{ Longitude } & \multirow{2}{*}{$\begin{array}{l}\text { Total } \\
\text { watershed } \\
\text { drainage } \\
\text { area, mi }\end{array}$} & \multirow{2}{*}{$\begin{array}{l}\text { Number } \\
\text { of } \\
\text { tributary } \\
\text { lakes }\end{array}$} & \multicolumn{2}{|c|}{$\begin{array}{c}\text { Impoundment } \\
\text { surface area, } \\
\mathrm{mi}^{2}\end{array}$} & \multirow{2}{*}{$\begin{array}{c}\text { Water- } \\
\text { shed area } \\
\text { controlled } \\
\text { by tributary } \\
\text { lakes, mi }\end{array}$} & \multicolumn{2}{|c|}{$\begin{array}{l}\text { Total watershed } \\
\text { area controlled }\end{array}$} & \multirow{2}{*}{$\begin{array}{c}\text { Geology } \\
\text { at site }\end{array}$} \\
\hline & & & & & & $\begin{array}{l}\text { tributary } \\
\text { lakes }\end{array}$ & $\begin{array}{l}\text { farm } \\
\text { ponds }\end{array}$ & & $\mathrm{mi}^{2}$ & percent & \\
\hline \multicolumn{12}{|c|}{ Obed River watershed synoptic sites } \\
\hline 03539701 & $\begin{array}{c}\text { Clear Creek above } \\
\text { Panther Creek } \\
\text { confluence }(1)\end{array}$ & $36^{\circ} 05^{\prime} 05^{\prime \prime}$ & $85^{\circ} 07^{\prime} 55^{\prime \prime}$ & 6.52 & 0 & 0 & 0.029 & 0 & 0.29 & 4.4 & $\mathrm{Pv}$ \\
\hline 03539703 & $\begin{array}{c}\text { Panther Creek } \\
\text { below Lake } \\
\text { Caryonah } \\
\text { Dam (2) }\end{array}$ & $36^{\circ} 04^{\prime} 16^{\prime \prime}$ & $85^{\circ} 07^{\prime} 52^{\prime \prime}$ & 1.61 & 1 & 0.047 & 0 & 1.61 & 1.61 & 100 & $\mathrm{PV}$ \\
\hline 03539704 & $\begin{array}{l}\text { Panther Creek } \\
\text { at Pugh } \\
\text { Cemetery (3) }\end{array}$ & $36^{\circ} 05^{\prime} 00^{\prime \prime}$ & $85^{\circ} 07^{\prime} 52^{\prime \prime}$ & 3.05 & 1 & 0.047 & 0.016 & 1.61 & 1.77 & 57.9 & $\mathrm{Pv}$ \\
\hline 03539705 & $\begin{array}{c}\text { Clear Creek below } \\
\text { Panther Creek } \\
\text { confluence (4) }\end{array}$ & $36^{\circ} 05^{\prime} 07^{\prime \prime}$ & $85^{\circ} 07^{\prime} 47^{\prime \prime}$ & 9.57 & 1 & 0.047 & 0.044 & 1.61 & 2.05 & 21.4 & $\mathrm{PV}$ \\
\hline 03539708 & $\begin{array}{l}\text { Clear Creek at } \\
\text { Clear Creek } \\
\text { Road (5) }\end{array}$ & $36^{\circ} 07^{\prime} 11^{\prime \prime}$ & $85^{\circ} 05^{\prime} 48^{\prime \prime}$ & 14.4 & 1 & 0.047 & 0.071 & 1.61 & 2.32 & 16.1 & $\mathrm{Pv}$ \\
\hline 03539710 & $\begin{array}{l}\text { Clear Creek nr } \\
\text { Rinnie (6) }\end{array}$ & $36^{\circ} 10^{\prime} 10^{\prime \prime}$ & $85^{\circ} 01^{\prime} 42^{\prime \prime}$ & 23.4 & 1 & 0.047 & 0.123 & 1.61 & 2.84 & 12.1 & $\mathrm{Pv}$ \\
\hline
\end{tabular}


Table 5. Synoptic-measurement and index sites in the Obed River watershed, Tennessee, 2003-2005.—Continued [mi², square miles; Pcf, Crooked Fork Group; Pr, Rockcastle Conglomerate; Pv, Vandever Formation]

\begin{tabular}{|c|c|c|c|c|c|c|c|c|c|c|c|}
\hline \multirow{2}{*}{$\begin{array}{l}\text { USGS } \\
\text { station } \\
\text { number }\end{array}$} & \multirow{2}{*}{$\begin{array}{l}\text { Site name } \\
\text { (number on } \\
\text { figure 3) }\end{array}$} & \multirow[t]{2}{*}{ Latitude } & \multirow[t]{2}{*}{ Longitude } & \multirow{2}{*}{$\begin{array}{l}\text { Total } \\
\text { watershed } \\
\text { drainage } \\
{\text { area, } \text { mi }^{2}}^{2}\end{array}$} & \multirow{2}{*}{$\begin{array}{c}\text { Number } \\
\text { of } \\
\text { tributary } \\
\text { lakes }\end{array}$} & \multicolumn{2}{|c|}{$\begin{array}{c}\text { Impoundment } \\
\text { surface area, } \\
\text { mi }^{2}\end{array}$} & \multirow{2}{*}{$\begin{array}{l}\text { Water- } \\
\text { shed area } \\
\text { controlled } \\
\text { by tributary } \\
\text { lakes, mi² }\end{array}$} & \multicolumn{2}{|c|}{$\begin{array}{l}\text { Total watershed } \\
\text { area controlled }\end{array}$} & \multirow{2}{*}{$\begin{array}{c}\text { Geology } \\
\text { at site }\end{array}$} \\
\hline & & & & & & $\begin{array}{l}\text { tributary } \\
\text { lakes }\end{array}$ & $\begin{array}{l}\text { farm } \\
\text { ponds }\end{array}$ & & $\mathrm{mi}^{2}$ & percent & \\
\hline \multicolumn{12}{|c|}{ Obed River watershed synoptic sites_-Continued } \\
\hline 03539715 & $\begin{array}{l}\text { No Business } \\
\text { Creek at Isoline } \\
\text { (7) }\end{array}$ & $36^{\circ} 05^{\prime} 23^{\prime \prime}$ & $85^{\circ} 03^{\prime} 51^{\prime \prime}$ & 2.85 & 0 & 0 & 0.026 & 0 & 0.26 & 9 & $\operatorname{Pr}$ \\
\hline 03539718 & $\begin{array}{l}\text { White Creek } \\
\text { above Cook } \\
\text { Creek conflu- } \\
\text { ence }(8)\end{array}$ & $36^{\circ} 10^{\prime} 43^{\prime \prime}$ & $84^{\circ} 47^{\prime} 59^{\prime \prime}$ & 19.1 & 0 & 0 & 0.05 & 0 & 0.5 & 2.6 & $\mathrm{Pv}$ \\
\hline 03539719 & $\begin{array}{l}\text { White Creek at } \\
\text { Twin Bridges } \\
\text { (9) }\end{array}$ & $36^{\circ} 10^{\prime} 39^{\prime \prime}$ & $84^{\circ} 48^{\prime} 01^{\prime \prime}$ & 38.4 & 0 & 0 & 0.229 & 0 & 2.29 & 5.9 & $\mathrm{Pv}$ \\
\hline 03539720 & $\begin{array}{l}\text { White Creek } \\
\text { at Lavendar } \\
\text { Bridge (10) }\end{array}$ & $36^{\circ} 09^{\prime} 32^{\prime \prime}$ & $84^{\circ} 47^{\prime} 20^{\prime \prime}$ & 45.3 & 0 & 0 & 0.253 & 0 & 2.53 & 5.6 & $\operatorname{Pr}$ \\
\hline 03539748 & $\begin{array}{l}\text { Little Clear Creek } \\
\text { nr Howard Mill } \\
\text { (11) }\end{array}$ & $36^{\circ} 07^{\prime} 48^{\prime \prime}$ & $84^{\circ} 43^{\prime} 21^{\prime \prime}$ & 10.6 & 0 & 0 & 0.024 & 0 & 0.24 & 2.3 & $\operatorname{Pr}$ \\
\hline 03538603 & $\begin{array}{c}\text { Obed River at US } \\
\text { Hwy } 70(12)\end{array}$ & $35^{\circ} 57^{\prime} 36^{\prime \prime}$ & $85^{\circ} 03^{\prime} 03^{\prime \prime}$ & 12.5 & 1 & 0.344 & 0.119 & 8.49 & 9.68 & 77.5 & $\operatorname{Pr}$ \\
\hline 03538813 & $\begin{array}{l}\text { Drowning Creek } \\
\text { above Copeland } \\
\text { Creek conflu- } \\
\text { ence (13) }\end{array}$ & $36^{\circ} 00^{\prime} 48^{\prime \prime}$ & $85^{\circ} 04^{\prime} 10^{\prime \prime}$ & 10 & 0 & 0 & 0.123 & 0 & 1.23 & 12.3 & $\mathrm{Pv}$ \\
\hline 03538814 & $\begin{array}{l}\text { Copeland Creek } \\
\text { above Drown- } \\
\text { ing Creek con- } \\
\text { fluence (14) }\end{array}$ & $36^{\circ} 00^{\prime} 31^{\prime \prime}$ & $85^{\circ} 04^{\prime} 14^{\prime \prime}$ & 10.7 & 0 & 0 & 0.1 & 0 & 1 & 9.4 & $\mathrm{Pv}$ \\
\hline 03538845 & $\begin{array}{l}\text { Fox Creek near } \\
\text { Lavendar Knob } \\
(03538845) \\
(15)\end{array}$ & $36^{\circ} 02^{\prime} 47^{\prime \prime}$ & $84^{\circ} 56^{\prime} 00^{\prime \prime}$ & 7.38 & 3 & 0.294 & 0.03 & 2.08 & 2.38 & 32.2 & $\operatorname{Pr}$ \\
\hline 03538865 & $\begin{array}{l}\text { Elmore Creek } \\
\text { near Genesis } \\
(03538865) \\
(16)\end{array}$ & $36^{\circ} 05^{\prime} 34^{\prime \prime}$ & $84^{\circ} 55^{\prime} 03^{\prime \prime}$ & 7.82 & 0 & 0 & 0.001 & 0 & 0.01 & 0.1 & $\mathrm{Pv}$ \\
\hline 03538871 & $\begin{array}{l}\text { Otter Creek at } \\
\text { Hebbertsburg } \\
(17)\end{array}$ & $36^{\circ} 03^{\prime} 16^{\prime \prime}$ & $84^{\circ} 51^{\prime} 20^{\prime \prime}$ & 16.9 & 2 & 0.477 & 0.051 & 5.35 & 5.86 & 34.7 & $\mathrm{Pv}$ \\
\hline 03538890 & $\begin{array}{l}\text { Daddys Creek } \\
\text { west of Brown } \\
\text { Gap (18) }\end{array}$ & $35^{\circ} 46^{\prime} 55^{\prime \prime}$ & $85^{\circ} 02^{\prime} 44^{\prime \prime}$ & 4.6 & 0 & 0 & 0.021 & 0 & 0.21 & 4.5 & $\operatorname{Pr}$ \\
\hline 03538900 & $\begin{array}{l}\text { Self Creek nr Big } \\
\quad \text { Lick (19) }\end{array}$ & $35^{\circ} 47^{\prime} 53^{\prime \prime}$ & $85^{\circ} 02^{\prime} 30^{\prime \prime}$ & 3.78 & 1 & 0.105 & 0 & 1.55 & 1.55 & 41 & $\operatorname{Pr}$ \\
\hline 03538940 & $\begin{array}{l}\text { Daddys Creek at } \\
\text { US Hwy } 127 \\
\text { near Big Lick } \\
\text { (20) }\end{array}$ & $35^{\circ} 48^{\prime \prime} 24^{\prime \prime}$ & $85^{\circ} 01^{\prime} 16^{\prime \prime}$ & 10.3 & 1 & 0.105 & 0.027 & 1.55 & 1.82 & 17.7 & Pcf \\
\hline
\end{tabular}




\section{Hydrologic Data for the Obed River Watershed, Tennessee}

Table 5. Synoptic-measurement and index sites in the Obed River watershed, Tennessee, 2003-2005. - Continued [mi², square miles; Pcf, Crooked Fork Group; Pr, Rockcastle Conglomerate; Pv, Vandever Formation]

\begin{tabular}{|c|c|c|c|c|c|c|c|c|c|c|c|}
\hline \multirow{2}{*}{$\begin{array}{l}\text { USGS } \\
\text { station } \\
\text { number }\end{array}$} & \multirow{2}{*}{$\begin{array}{c}\text { Site name } \\
\text { (number on } \\
\text { figure 3) }\end{array}$} & \multirow{2}{*}{ Latitude } & \multirow{2}{*}{ Longitude } & \multirow{2}{*}{$\begin{array}{c}\text { Total } \\
\text { watershed } \\
\text { drainage } \\
{\text { area, } \text { mi }^{2}}^{2}\end{array}$} & \multirow{2}{*}{$\begin{array}{l}\text { Number } \\
\text { of } \\
\text { tributary } \\
\text { lakes }\end{array}$} & \multicolumn{2}{|c|}{$\begin{array}{c}\text { Impoundment } \\
\text { surface area, } \\
\mathrm{mi}^{2}\end{array}$} & \multirow{2}{*}{$\begin{array}{c}\text { Water- } \\
\text { shed area } \\
\text { controlled } \\
\text { by tributary } \\
\text { lakes, mi }\end{array}$} & \multicolumn{2}{|c|}{$\begin{array}{l}\text { Total watershed } \\
\text { area controlled }\end{array}$} & \multirow{2}{*}{$\begin{array}{l}\text { Geology } \\
\text { at site }\end{array}$} \\
\hline & & & & & & $\begin{array}{l}\text { tributary } \\
\text { lakes }\end{array}$ & $\begin{array}{l}\text { farm } \\
\text { ponds }\end{array}$ & & $\mathrm{mi}^{2}$ & percent & \\
\hline 03538950 & $\begin{array}{l}\text { Lick Creek at Big } \\
\text { Lick (21) }\end{array}$ & $35^{\circ} 48^{\prime \prime} 23^{\prime \prime}$ & $85^{\circ} 12^{\prime} 13^{\prime \prime}$ & 8.53 & 0 & 0 & 0.083 & 0 & 0.83 & 9.7 & Pcf \\
\hline 03538990 & $\begin{array}{l}\text { Basses Creek be- } \\
\text { low Lake Tansi } \\
\text { at US Hwy } 127 \\
\text { (22) }\end{array}$ & $35^{\circ} 51^{\prime} 05^{\prime \prime}$ & $85^{\circ} 00^{\prime} 43^{\prime \prime}$ & 13.1 & 1 & 0.664 & 0.033 & 4.45 & 4.78 & 36.5 & $\operatorname{Pr}$ \\
\hline 03539200 & $\begin{array}{c}\text { Byrd Creek at US } \\
\text { Hwy } 127 \text { (23) }\end{array}$ & $35^{\circ} 54^{\prime} 41 "$ & $84^{\circ} 59^{\prime 2} 29^{\prime \prime}$ & 10.3 & 3 & 0.165 & 0.099 & 9.13 & 10.1 & 98.3 & $\operatorname{Pr}$ \\
\hline 03539250 & $\begin{array}{l}\text { Byrd Creek below } \\
\text { Ward Creek } \\
\text { confluence (24) }\end{array}$ & $35^{\circ} 55^{\prime} 55^{\prime \prime}$ & $84^{\circ} 57^{\prime} 03^{\prime \prime}$ & 24.8 & 3 & 0.165 & 0.193 & 9.13 & 11.1 & 44.6 & $\operatorname{Pr}$ \\
\hline 03539502 & $\begin{array}{l}\text { North Creek } \\
\text { above Brown } \\
\text { Creek conflu- } \\
\text { ence }(25)\end{array}$ & $35^{\circ} 57^{\prime} 41^{\prime \prime}$ & $84^{\circ} 56^{\prime} 25^{\prime \prime}$ & 5.19 & 1 & 0.164 & 0.051 & 1.24 & 1.75 & 33.7 & $\operatorname{Pr}$ \\
\hline 03539503 & $\begin{array}{l}\text { Brown Creek } \\
\text { above North } \\
\text { Creek conflu- } \\
\text { ence (26) }\end{array}$ & $35^{\circ} 57^{\prime} 41^{\prime \prime}$ & $84^{\circ} 56^{\prime} 10^{\prime \prime}$ & 6.44 & 1 & 0.33 & 0.035 & 2.5 & 2.85 & 44.2 & $\operatorname{Pr}$ \\
\hline 03539680 & $\begin{array}{l}\text { Yellow Creek east } \\
\text { of Cline School } \\
\text { (27) }\end{array}$ & $36^{\circ} 00^{\prime} 07^{\prime \prime}$ & $84^{\circ} 47^{\prime} 03^{\prime \prime}$ & 9.97 & 0 & 0 & 0.006 & 0 & 0.06 & 0.6 & $\operatorname{Pr}$ \\
\hline \multicolumn{12}{|c|}{ Obed River watershed index sites } \\
\hline 03539600 & $\begin{array}{l}\text { Daddys Creek } \\
\text { near Hebberts- } \\
\text { burg (28) }\end{array}$ & $35^{\circ} 59^{\prime} 51^{\prime \prime}$ & $84^{\circ} 49^{\prime} 21^{\prime \prime}$ & 139 & 12 & 1.72 & 0.675 & 25.2 & 32 & 23 & $\mathrm{Pv}$ \\
\hline 03539778 & $\begin{array}{l}\text { Clear Creek at } \\
\text { Lilly Bridge } \\
\text { (29) }\end{array}$ & $36^{\circ} 06^{\prime} 11^{\prime \prime}$ & $84^{\circ} 43^{\prime} 06^{\prime \prime}$ & 170 & 1 & 0.047 & 0.703 & 1.61 & 8.64 & 5.1 & $\mathrm{Pv}$ \\
\hline 03539800 & $\begin{array}{l}\text { Obed River near } \\
\text { Lancing (30) }\end{array}$ & $36^{\circ} 04^{\prime} 53^{\prime \prime}$ & $84^{\circ} 40^{\prime} 13^{\prime \prime}$ & 518 & 20 & 2.92 & 2.54 & 43.5 & 68.9 & 13.3 & $\mathrm{Pv}$ \\
\hline
\end{tabular}


of impoundments in the Obed River watershed are located in areas that are underlain by the Rockcastle ConglomerateCrooked Fork Group. The unit discharge of the Obed River near Lancing was used as an index to divide synoptic measurements into high- or low-baseflow categories. Measurements made when the unit discharge at the index site was greater than 0.1 cubic foot per second per square mile $\left[\left(\mathrm{ft}^{3} / \mathrm{s}\right) / \mathrm{mi}^{2}\right]$ were categorized as high baseflow, while all other synoptic measurements were categorized as low baseflow (appendix 1).

\section{Precipitation and Streamflow}

The average annual rainfall measured at the Crossville Experiment Station is about 57 inches for the 82-year period from 1930 through 2012 (National Climatic Data Center, 2014). Annual and cumulative departures from the 82-year average rainfall illustrate a pattern of generally higher rainfall since about 1970 (fig. 5). This pattern is consistent with results from numerous national and regional studies, which have documented a relatively abrupt increase in precipitation of 10 to 20 percent across the southeastern United States beginning about 1970 (Groisman and Easterling, 1994; Lettenmaier and others, 1994; Karl and others, 1996; Karl and Knight, 1998; Lins and Slack, 1999; Douglas and others, 2000; Easterling and others, 2000; Burkett and others, 2001; Groisman and others, 2001; McCabe and Wolock, 2002; Wolfe and others, 2003; Lins, 2005).

Annual flow-duration curves for the Emory River at Oakdale indicate recent historical change in hydrologic response at low flows, specifically an increase in the minimum values of the lowest flows since 1970 (fig. 6). Eighteen of 40 years between 1930 and 1970 had values for the 0.5 th percentile flow of less than 3 cubic feet per second $\left(\mathrm{ft}^{3} / \mathrm{s}\right)$. In contrast, the 42 years between 1970 and 2012 include only 2 years with values for the 0.5 th percentile flow as low as $3 \mathrm{ft}^{3} / \mathrm{s}$. This difference may partly reflect increases in regional rainfall after
1970 and evidenced by a general increase in average annual runoff post-1970 (fig. 5). However, increased average rainfall does not explain elevated low flows during periods of severe and sustained regional drought.

Comparison of the drought of 1952-54 with that of 2007-09 is instructive (table 6). Each drought was preceded by a similar wet period having about 600 inches of precipitation during the previous decade, and the first year of each drought had below average annual precipitation of about 40 inches. Moreover, both droughts produced discernible hydrologic effects during periods of about 3 years. The 1952-54 drought produced a minimum annual 0.5 th percentile flow of $0.002 \mathrm{ft}^{3} / \mathrm{s}$. By comparison, the 2007-09 drought produced minimum annual 0.5 th percentile flow of $3 \mathrm{ft}^{3} / \mathrm{s}$, which is more than 4 orders higher than that of the 1952-54 drought and equal to the 0.5 th percentile flows after 1970 (fig. 6; table 6). Among known hydrologic changes in the Obed River watershed, increased wastewater return flows appear to be a likely explanatory factor in the sustainment of low flows during periods of severe drought.

Wastewater return flows for the 1950 s are not readily available; however, census data show that the population of Cumberland County was relatively stable at about 19,000 to 21,000 persons between 1950 and 1970 (Center for Business and Economic Research, 2014). Beginning in 1970, the population of Cumberland County increased by 6,000 to 12,000 persons per decade, exceeding 54,000 by 2010 (table 1). Between 1995 and 2012, average return flows from the Crossville WWTP have ranged from 2.5 to $4.5 \mathrm{ft}^{3} / \mathrm{s}$, with only 3 of 19 years falling below $3 \mathrm{ft}^{3} / \mathrm{s}$ (Robbie Baker, Tennessee Department of Environment and Conservation, written commun., 2010; City of Crossville, written commun., 2014; Veolia Water North America, written commun., 2014). It follows that wastewater return flows from Crossville are of sufficient magnitude to maintain low flows at or above $3 \mathrm{ft}^{3} / \mathrm{s}$. 


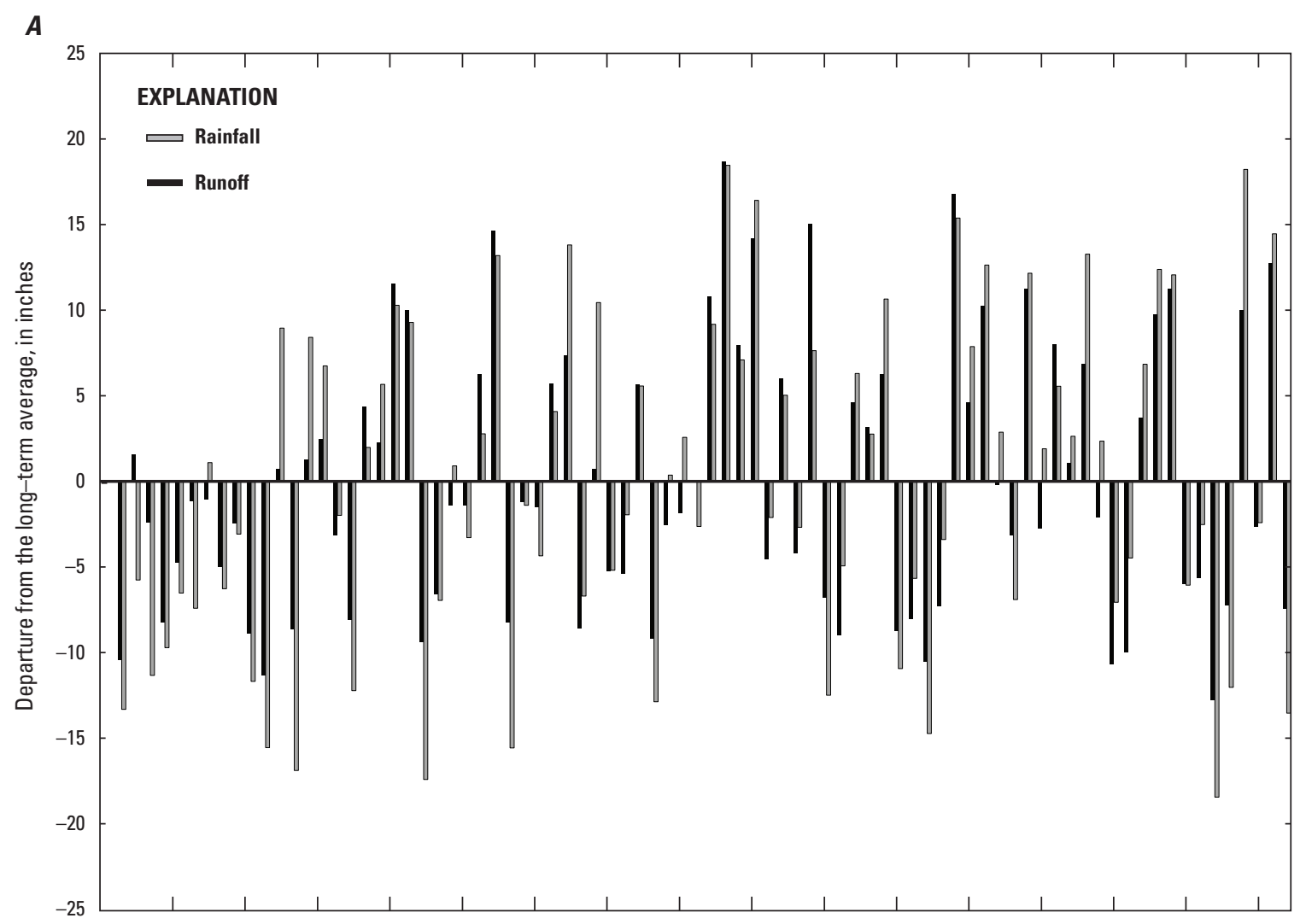

B

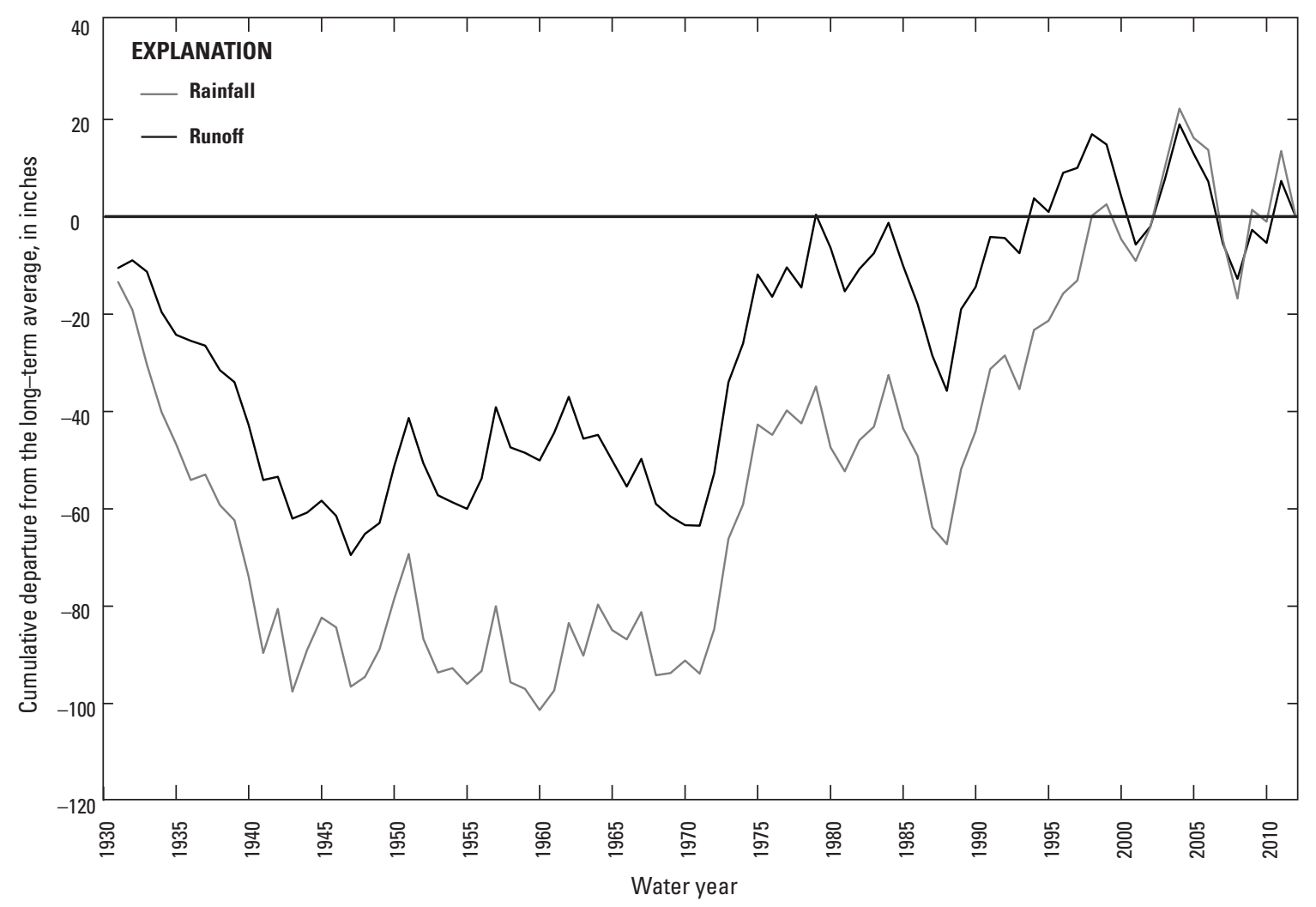

Figure 5. $A$, Annual and $B$, cumulative departures from average for annual rainfall at Crossville and annual runoff at the Emory River at Oakdale streamgage, 1930 through 2012. 


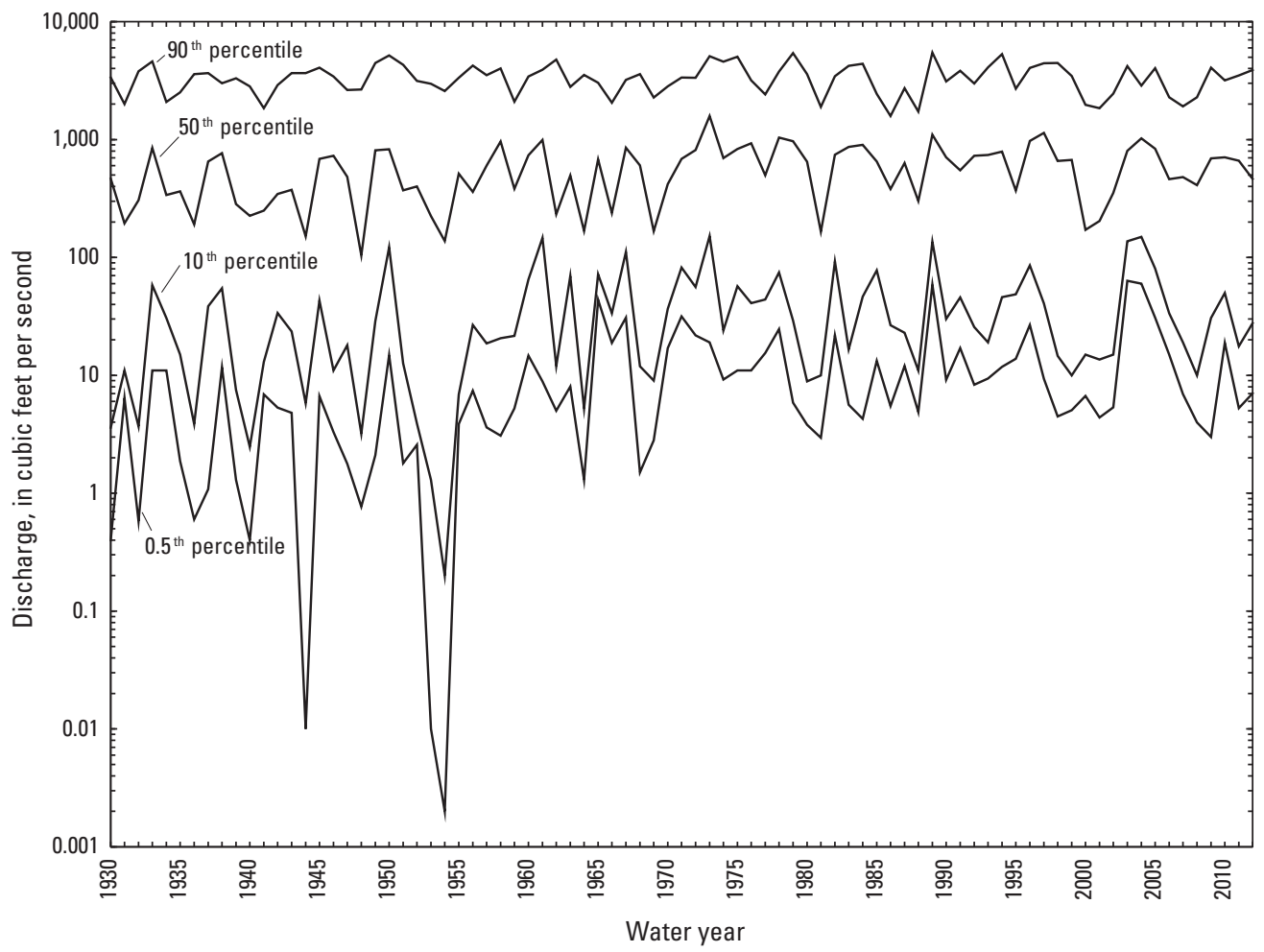

Figure 6. Annual flow-duration relations for Emory River at Oakdale, Tennessee, 1930 through 2012.

Table 6. Comparison of precipitation and resulting streamflows for two regional droughts in the Obed River Basin, 1952-2009.

[Precipitation data for Crossville Experiment Station, National Climatic Data Center, 2014; 0.5th percentile flows based on Emory River at Oakdale, 1930-2012; average annual wastewater release based on written communication from Robbie Baker, Tennessee Department of Environment and Conservation, 2010 and City of Crossville, Veolia Water North America, 2014; ft³/s, cubic feet per second; -, data unavailable]

\begin{tabular}{|c|c|c|c|c|c|}
\hline \multirow{2}{*}{ Drought period } & \multicolumn{2}{|c|}{ Total precipitation (inches) } & \multirow{2}{*}{$\begin{array}{l}\text { Annual precipita- } \\
\text { tion for drought year } \\
\text { (inches) }\end{array}$} & \multirow{2}{*}{$\begin{array}{l}\text { 0.5th percentile } \\
\text { flow }\left(\mathrm{ft}^{3} / \mathrm{s}\right)\end{array}$} & \multirow{2}{*}{$\begin{array}{c}\text { Average annual } \\
\text { wastewater release } \\
\left(\mathrm{ft}^{3} / \mathbf{s}\right)\end{array}$} \\
\hline & Previous 10 years & Pervious 5 years & & & \\
\hline 1952 & 594 & 302 & 39.97 & 2.57 & - \\
\hline 1953 & 567 & 296 & 50.43 & 0.01 & - \\
\hline 1954 & 577 & 288 & 58.3 & 0.002 & - \\
\hline 2007 & 603 & 309 & 40 & 6.932 & 2.8 \\
\hline 2008 & 582 & 284 & 45.35 & 3.983 & 3.08 \\
\hline 2009 & 557 & 260 & 75.61 & 3 & 3.8 \\
\hline
\end{tabular}




\section{Synoptic Analysis}

Comparison of average unit discharge measured during high- and low-baseflow conditions with the percentage of watershed area controlled by impoundments shows that under high-baseflow conditions, unit discharge decreases as the percentage of watershed controlled by impoundments increases (table 7; fig. 7). Under low-baseflow conditions, unit discharge shows a weaker tendency to increase with increased percentage of drainage area controlled by impoundments (table 8; fig. 7). These observations are broadly consistent with the analysis of Smith and others (2002), who noted an increase in water retention, evapotranspiration, and groundwater recharge as effects of small impoundments. Under storm and highbaseflow conditions, impoundments retain water that would otherwise flow down the channel, thereby reducing streamflow magnitude downstream. Under low-baseflow conditions, some of the retained water seeps through, under, or around dams, thereby elevating downstream baseflow.

In the Obed River watershed, the relation between low baseflow and impoundments is most evident for basins primarily underlain by the Vandever Formation. Flow measurements from such basins define the upper envelope of the generally positive relation between low baseflow and percentage of drainage area controlled by impoundments (fig. 7). As previously noted, the Vandever Formation functions as a local confining unit, and outcrops of this formation commonly coincide with seeps and springs, except when breached by erosion. The low-baseflow effect of impoundments tends to further stabilize and elevate the low baseflows in the Obed WSR that are already augmented by effluent releases from the WWTP.

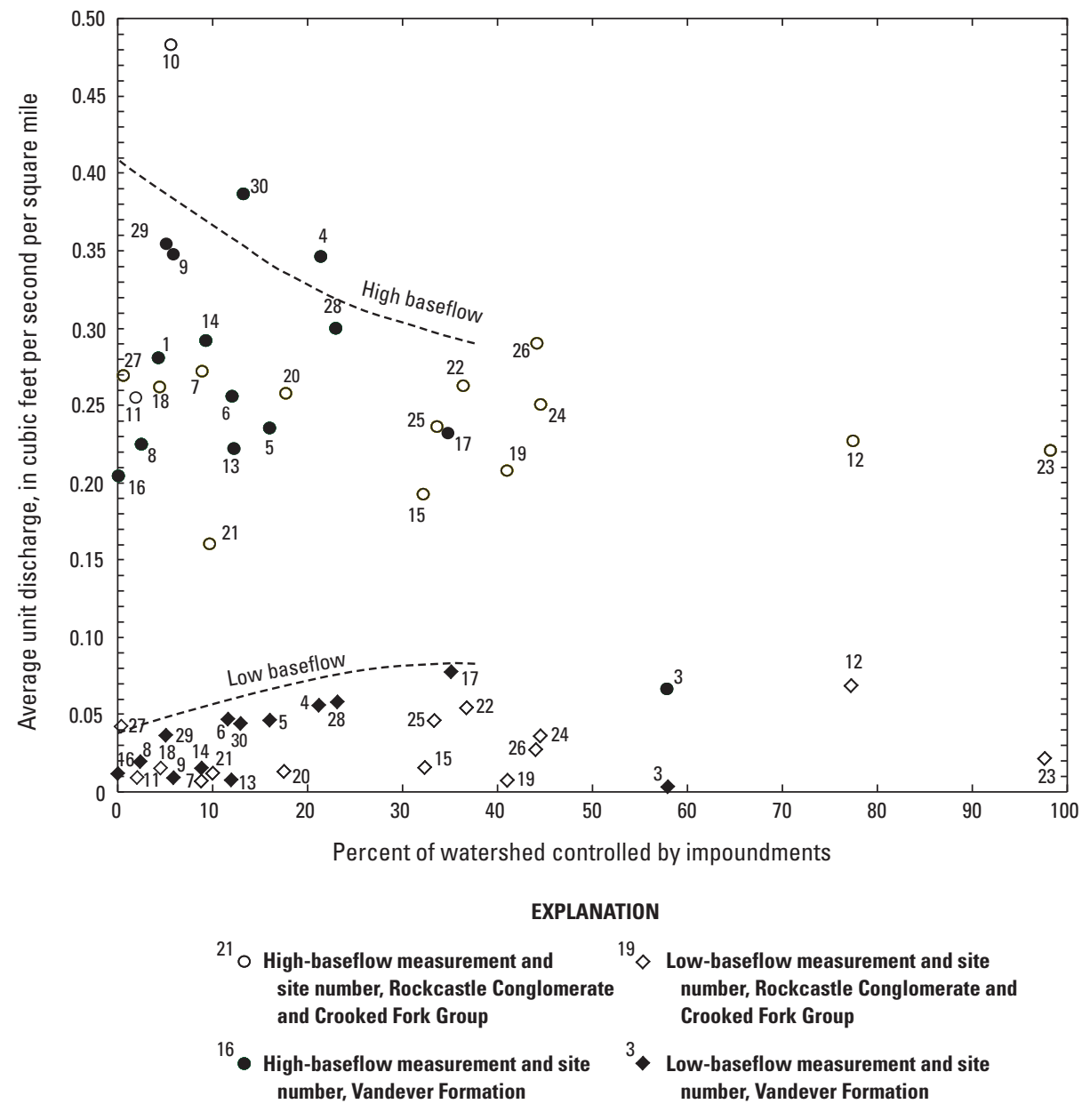

See tables 5, 6, and 7 for site descriptions and data

Figure 7. Average high- and low-baseflow discharge measurements and the percentages of the Obed River watershed controlled by impoundments, 2003-2005. 
Table 7. High-baseflow synoptic measurements for the Obed River watershed, Tennessee, 2003-2005.

$\left[\mathrm{mi}^{2}\right.$, square mile; $\left(\mathrm{ft}^{3} / \mathrm{s}\right) / \mathrm{mi}^{2}$, cubic feet per second per square mile; See appendix 1 for discharge measurement data]

\begin{tabular}{|c|c|c|c|c|c|c|}
\hline $\begin{array}{l}\text { Site number } \\
\text { (on fig. 3) }\end{array}$ & Site name & $\begin{array}{l}\text { Drainage area, } \\
\mathrm{mi}^{2}\end{array}$ & $\begin{array}{c}\text { Number of } \\
\text { discharge } \\
\text { measure- } \\
\text { ments }\end{array}$ & $\begin{array}{c}\text { Average unit } \\
\text { discharge } \\
\left(\mathrm{ft}^{3} / \mathrm{s}\right) / \mathrm{mi}^{2}\end{array}$ & $\begin{array}{c}\text { Drainage area } \\
\text { controlled, } \\
\text { percent }\end{array}$ & $\begin{array}{l}\text { Selected impoundments in } \\
\text { the watershed }\end{array}$ \\
\hline \multicolumn{7}{|c|}{ Rockcastle Conglomerate and Crooked Fork Group sites } \\
\hline 7 & $\begin{array}{l}\text { No Business Creek at US } \\
\text { Hwy } 127\end{array}$ & 2.85 & 3 & 0.271 & 9 & farm ponds \\
\hline 10 & $\begin{array}{l}\text { White Creek at Lavendar } \\
\text { Bridge at State Route } 62\end{array}$ & 45.3 & 2 & 0.482 & 5.6 & farm ponds \\
\hline 11 & $\begin{array}{l}\text { Little Clear Creek at State } \\
\text { Route } 62\end{array}$ & 10.6 & 3 & 0.255 & 2.3 & farm ponds \\
\hline 12 & Obed River at US Hwy 70 & 12.5 & 4 & 0.228 & 77.5 & Lake Holiday \\
\hline 15 & $\begin{array}{l}\text { Fox Creek near Lavendar } \\
\text { Knob }\end{array}$ & 7.38 & 4 & 0.193 & 32.2 & $\begin{array}{l}\text { Fox Creek Lake, Frances Lake, } \\
\text { Good Neighbor Lake }\end{array}$ \\
\hline 18 & $\begin{array}{l}\text { Daddys Creek west of } \\
\text { Brown Gap }\end{array}$ & 4.6 & 4 & 0.263 & 4.5 & farm ponds \\
\hline 19 & $\begin{array}{l}\text { Self Creek at Big Lick Road } \\
\text { near Big Lick }\end{array}$ & 3.78 & 4 & 0.204 & 41 & Lake Breckenridge $\# 1$ and $\# 2$ \\
\hline 20 & $\begin{array}{l}\text { Daddys Creek at US Hwy } \\
127 \text { near Big Lick }\end{array}$ & 10.3 & 4 & 0.257 & 17.7 & Lake Breckenridge $\# 1$ and $\# 2$ \\
\hline 21 & Lick Creek at US Hwy 127 & 8.53 & 4 & 0.16 & 9.7 & farm ponds \\
\hline 22 & $\begin{array}{l}\text { Basses Creek below Lake } \\
\text { Tansi at US Hwy } 127\end{array}$ & 13.1 & 4 & 0.261 & 36.5 & Lake Tansi \\
\hline 23 & Byrd Creek at US Hwy 127 & 10.3 & 4 & 0.22 & 98.3 & $\begin{array}{l}\text { Lake Mohawk, Lake Geronimo, } \\
\text { Byrd Lake }\end{array}$ \\
\hline 24 & $\begin{array}{l}\text { Byrd Creek below Ward } \\
\text { Creek confluence }\end{array}$ & 24.8 & 4 & 0.251 & 44.6 & Byrd Lake \\
\hline 25 & $\begin{array}{l}\text { North Creek above Brown } \\
\text { Creek confluence }\end{array}$ & 5.19 & 3 & 0.239 & 33.7 & Lake Turner \\
\hline 26 & $\begin{array}{l}\text { Brown Creek above North } \\
\text { Creek confluence }\end{array}$ & 6.44 & 4 & 0.288 & 44.2 & Lake St. George \\
\hline 27 & $\begin{array}{l}\text { Yellow Creek east of Cline } \\
\text { School }\end{array}$ & 9.97 & 3 & 0.264 & 0.6 & farm ponds \\
\hline \multicolumn{7}{|c|}{ Vandever Formation sites } \\
\hline 1 & $\begin{array}{l}\text { Clear Creek above Panther } \\
\text { Creek confluence }\end{array}$ & 6.52 & 3 & 0.28 & 4.4 & farm ponds \\
\hline 3 & $\begin{array}{l}\text { Panther Creek at Pugh } \\
\text { Cemetery }\end{array}$ & 3.05 & 2 & 0.066 & 57.9 & Lake Caryonah \\
\hline 4 & $\begin{array}{l}\text { Clear Creek below Panther } \\
\text { Creek confluence }\end{array}$ & 9.57 & 2 & 0.345 & 21.4 & farm ponds \\
\hline 5 & $\begin{array}{l}\text { Clear Creek at Clear Creek } \\
\text { Road }\end{array}$ & 14.4 & 3 & 0.236 & 16.1 & farm ponds \\
\hline 6 & Clear Creek at US Hwy 127 & 23.4 & 3 & 0.256 & 12.1 & farm ponds \\
\hline 8 & $\begin{array}{l}\text { White Creek above Cook } \\
\text { Creek confluence }\end{array}$ & 19.1 & 3 & 0.227 & 2.6 & farm ponds \\
\hline 9 & $\begin{array}{l}\text { White Creek below Cook } \\
\text { Creek confluence }\end{array}$ & 38.6 & 4 & 0.349 & 5.9 & farm ponds \\
\hline 13 & $\begin{array}{l}\text { Drowning Creek above Co- } \\
\text { peland Creek confluence }\end{array}$ & 10 & 3 & 0.223 & 12.3 & farm ponds \\
\hline
\end{tabular}


Table 7. High-baseflow synoptic measurements for the Obed River watershed, Tennessee, 2003-2005.—Continued $\left[\mathrm{mi}^{2}\right.$, square mile; $\left(\mathrm{ft}^{3} / \mathrm{s}\right) / \mathrm{mi}^{2}$, cubic feet per second per square mile; See appendix 1 for discharge measurement data]

\begin{tabular}{|c|c|c|c|c|c|c|}
\hline $\begin{array}{l}\text { Site number } \\
\text { (on fig. 3) }\end{array}$ & Site name & $\begin{array}{l}\text { Drainage area, } \\
\mathrm{mi}^{2}\end{array}$ & $\begin{array}{l}\text { Number of } \\
\text { discharge } \\
\text { measure- } \\
\text { ments }\end{array}$ & $\begin{array}{c}\text { Average unit } \\
\text { discharge } \\
\left(\mathrm{ft}^{3} / \mathrm{s}\right) / \mathrm{mi}^{2}\end{array}$ & $\begin{array}{c}\text { Drainage area } \\
\text { controlled, } \\
\text { percent }\end{array}$ & $\begin{array}{l}\text { Selected impoundments in } \\
\text { the watershed }\end{array}$ \\
\hline \multicolumn{7}{|c|}{ Vandever Formation sites_-Continued } \\
\hline 14 & $\begin{array}{l}\text { Copeland Creek above } \\
\text { Drowning Creek } \\
\text { confluence }\end{array}$ & 10.7 & 4 & 0.291 & 9.4 & farm ponds \\
\hline 16 & Elmore Creek near Genesis & 7.82 & 4 & 0.206 & 0.1 & farm ponds \\
\hline 17 & $\begin{array}{l}\text { Otter Creek at Catoosa } \\
\text { Road }\end{array}$ & 16.9 & 4 & 0.234 & 34.7 & Stone Lake, Lake Dartmoor \\
\hline 28 & $\begin{array}{l}\text { Daddys Creek near } \\
\text { Hebbertsburg }\end{array}$ & 139 & 4 & 0.299 & 23 & $\begin{array}{l}\text { Lake Tansi, Lake Turner, Lake } \\
\text { Glastowbury, others }\end{array}$ \\
\hline 29 & Clear Creek at Lilly Bridge & 170 & 3 & 0.353 & 5.1 & farm ponds \\
\hline 30 & Obed River near Lancing & 518 & 4 & 0.387 & 13.3 & $\begin{array}{l}\text { Lake Holiday, Lake Dartmoor, } \\
\text { Lake Tansi, others }\end{array}$ \\
\hline
\end{tabular}

Table 8. Low-baseflow synoptic measurements for the Obed River watershed, Tennessee, 2003-2005.

$\left[\mathrm{mi}^{2}\right.$, square mile; $\left(\mathrm{ft}^{3} / \mathrm{s}\right) / \mathrm{mi}^{2}$, cubic feet per second per square mile; See appendix 1 for discharge measurement data]

\begin{tabular}{|c|c|c|c|c|c|c|}
\hline $\begin{array}{l}\text { Site number } \\
\text { (on fig. 3) }\end{array}$ & Site name & $\begin{array}{l}\text { Drainage area, } \\
\mathrm{mi}^{2}\end{array}$ & $\begin{array}{c}\text { Number of } \\
\text { discharge } \\
\text { measure- } \\
\text { ments }\end{array}$ & $\begin{array}{c}\text { Average unit } \\
\text { discharge } \\
\left(\mathrm{ft}^{3} / \mathrm{s}\right) / \mathrm{mi}^{2}\end{array}$ & $\begin{array}{l}\text { Drain- } \\
\text { age area } \\
\text { controlled, } \\
\text { percent }\end{array}$ & $\begin{array}{l}\text { Selected impoundments in } \\
\text { the watershed }\end{array}$ \\
\hline \multicolumn{7}{|c|}{ Rockcastle Conglomerate and Crooked Fork Group sites } \\
\hline 7 & $\begin{array}{l}\text { No Business Creek at US } \\
\text { Hwy } 127\end{array}$ & 2.85 & 3 & 0.009 & 9 & farm ponds \\
\hline 11 & $\begin{array}{l}\text { Little Clear Creek at State } \\
\text { Route } 62\end{array}$ & 10.6 & 3 & 0.013 & 2.3 & farm ponds \\
\hline 12 & Obed River at US Hwy 70 & 12.5 & 3 & 0.067 & 77.5 & Lake Holiday \\
\hline 15 & $\begin{array}{l}\text { Fox Creek near Lavendar } \\
\text { Knob }\end{array}$ & 7.38 & 3 & 0.017 & 32.2 & $\begin{array}{l}\text { Fox Creek Lake, Frances Lake, } \\
\text { Good Neighbor Lake }\end{array}$ \\
\hline 18 & $\begin{array}{l}\text { Daddys Creek west of } \\
\text { Brown Gap }\end{array}$ & 4.6 & 3 & 0.015 & 4.5 & farm ponds \\
\hline 19 & $\begin{array}{l}\text { Self Creek at Big Lick Road } \\
\text { near Big Lick }\end{array}$ & 3.78 & 3 & 0.007 & 41 & Lake Breckenridge \#1 and \#2 \\
\hline 20 & $\begin{array}{l}\text { Daddys Creek at US Hwy } \\
127 \text { near Big Lick }\end{array}$ & 10.3 & 3 & 0.015 & 17.7 & Lake Breckenridge \#1 and \#2 \\
\hline 21 & Lick Creek at US Hwy 127 & 8.53 & 3 & 0.013 & 9.7 & farm ponds \\
\hline 22 & $\begin{array}{c}\text { Basses Creek below Lake } \\
\text { Tansi at US Hwy } 127\end{array}$ & 13.1 & 3 & 0.052 & 36.5 & Lake Tansi \\
\hline 23 & Byrd Creek at US Hwy 127 & 10.3 & 3 & 0.022 & 98.3 & $\begin{array}{l}\text { Lake Mohawk, Lake Geronimo, } \\
\text { Byrd Lake }\end{array}$ \\
\hline 24 & $\begin{array}{l}\text { Byrd Creek below Ward } \\
\text { Creek confluence }\end{array}$ & 24.8 & 2 & 0.031 & 44.6 & Byrd Lake \\
\hline 25 & $\begin{array}{l}\text { North Creek above Brown } \\
\text { Creek confluence }\end{array}$ & 5.19 & 3 & 0.043 & 33.7 & Lake Turner \\
\hline
\end{tabular}


Table 8. Low-baseflow synoptic measurements for the Obed River watershed, Tennessee, 2003-2005. - Continued

$\left[\mathrm{mi}^{2}\right.$, square mile; $\left(\mathrm{ft}^{3} / \mathrm{s}\right) / \mathrm{mi}^{2}$, cubic feet per second per square mile; See appendix 1 for discharge measurement data]

\begin{tabular}{|c|c|c|c|c|c|c|}
\hline $\begin{array}{l}\text { Site number } \\
\text { (on fig. 3) }\end{array}$ & Site name & $\begin{array}{l}\text { Drainage area, } \\
\mathrm{mi}^{2}\end{array}$ & $\begin{array}{c}\text { Number of } \\
\text { discharge } \\
\text { measure- } \\
\text { ments }\end{array}$ & $\begin{array}{l}\text { Average unit } \\
\text { discharge } \\
\left(\mathrm{ft}^{3} / \mathrm{s}\right) / \mathrm{mi}^{2}\end{array}$ & $\begin{array}{c}\text { Drain- } \\
\text { age area } \\
\text { controlled, } \\
\text { percent }\end{array}$ & $\begin{array}{l}\text { Selected impoundments in } \\
\text { the watershed }\end{array}$ \\
\hline \multicolumn{7}{|c|}{ Rockcastle Conglomerate and Crooked Fork Group sites-Continued } \\
\hline 26 & $\begin{array}{l}\text { Brown Creek above North } \\
\text { Creek confluence }\end{array}$ & 6.44 & 3 & 0.029 & 44.2 & Lake St. George \\
\hline 27 & $\begin{array}{l}\text { Yellow Creek east of Cline } \\
\text { School }\end{array}$ & 9.97 & 2 & 0.046 & 0.6 & farm ponds \\
\hline \multicolumn{7}{|c|}{ Vandever Formation sites } \\
\hline 3 & $\begin{array}{l}\text { Panther Creek at Pugh } \\
\text { Cemetery }\end{array}$ & 3.05 & 1 & 0 & 57.9 & Lake Caryonah \\
\hline 4 & $\begin{array}{l}\text { Clear Creek below Panther } \\
\text { Creek confluence }\end{array}$ & 9.57 & 1 & 0.056 & 21.4 & farm ponds \\
\hline 5 & $\begin{array}{l}\text { Clear Creek at Clear Creek } \\
\text { Road }\end{array}$ & 14.4 & 3 & 0.047 & 16.1 & farm ponds \\
\hline 6 & Clear Creek at US Hwy 127 & 23.4 & 3 & 0.049 & 12.1 & farm ponds \\
\hline 8 & $\begin{array}{l}\text { White Creek above Cook } \\
\text { Creek confluence }\end{array}$ & 19.1 & 1 & 0.018 & 2.6 & farm ponds \\
\hline 9 & $\begin{array}{l}\text { White Creek below Cook } \\
\text { Creek confluence }\end{array}$ & 38.6 & 3 & 0.013 & 5.9 & farm ponds \\
\hline 13 & $\begin{array}{l}\text { Drowning Creek above Co- } \\
\text { peland Creek confluence }\end{array}$ & 10 & 3 & 0.007 & 12.3 & farm ponds \\
\hline 14 & $\begin{array}{l}\text { Copeland Creek above } \\
\text { Drowning Creek conflu- } \\
\text { ence }\end{array}$ & 10.7 & 3 & 0.013 & 9.4 & farm ponds \\
\hline 16 & Elmore Creek near Genesis & 7.82 & 3 & 0.013 & 0.1 & farm ponds \\
\hline 17 & $\begin{array}{l}\text { Otter Creek at Catoosa } \\
\text { Road }\end{array}$ & 16.9 & 3 & 0.077 & 34.7 & Stone Lake, Lake Dartmoor \\
\hline 28 & $\begin{array}{l}\text { Daddys Creek near Heb- } \\
\text { bertsburg }\end{array}$ & 139 & 3 & 0.059 & 23 & $\begin{array}{l}\text { Lake Tansi, Lake Turner, Lake } \\
\text { Glastowbury, others }\end{array}$ \\
\hline 29 & Clear Creek at Lilly Bridge & 170 & 3 & 0.035 & 5.1 & farm ponds \\
\hline 30 & Obed River near Lancing & 518 & 3 & 0.047 & 13.3 & $\begin{array}{l}\text { Lake Holiday, Lake Dartmoor } \\
\text { Lake Tansi, others }\end{array}$ \\
\hline
\end{tabular}

\section{Summary and Conclusions}

The data and observations presented in this report support the following conclusions:

1. Increased rainfall since 1970 has generally contributed to an increase in baseflows in the Obed WSR but does not fully explain increases in the lowest flow percentiles, which persist even during periods of historical drought;
2. The combination of headwater impoundments and wastewater treatment inflows appear to have generally stabilized and increased low baseflow in late summer and early fall; and

3. Climatic and human influences on streamflow conditions are either dampened or amplified by geologic controls on streamflow response, notably the tendency of the sandstones of the Rockcastle Conglomerate to accept infiltration and the tendency of the shales of the Vandever Formation to prevent infiltration and direct groundwater discharge to streams. 


\section{Acknowledgments}

The authors thank Jeffrey C. Hughes and Steven Bakaletz of the National Park Service and W. Scott Gain and Michael W. Bradley of the U.S. Geological Survey for their support, assistance, and input to the study and this report. The National Park Service and the Tennessee Wildlife Resources Agency provided the support necessary to establish, reactivate, and maintain continuous-record gaging stations on the Obed River, Clear Creek, and Daddys Creek.

\section{References}

Arnwine, D.H., Sparks, K.J., and James, R.R., 2006, Probabilistic monitoring of streams below small impoundments in Tennessee: Tennessee Department of Environment and Conservation, $276 \mathrm{p}$.

Bohac, C.E., and McCall, M.J., 2008, Water use in the Tennessee Valley for 2005 and projected use in 2030: Tennessee Valley Authority, 100 p., variously paged.

Bradfield, A.D., 1986a, Benthic invertebrate population characteristics as affected by water quality in coal-bearing regions of Tennessee: U.S. Geological Survey WaterResources Investigations Report 85-4227, 19 p.

Bradfield, A.D., 1986b, Evaluation of coal-mining impacts using numerical classification of benthic invertebrate data from streams draining a heavily mined basin in eastern Tennessee: U.S. Geological Survey WaterResources Investigations Report 85-4289, 59 p.

Brahana, J.V., Macy, J.A., Mulderink, D.M., and Zemo, D.A., 1986, Preliminary delineation and description of the regional aquifers of Tennessee - Cumberland Plateau aquifer system: U.S. Geological Survey WaterResources Investigations/Open-File Report 82-338, $24 \mathrm{p}$.

Bureau of Outdoor Recreation, 1976a, Obed River, Tennessee, Wild and Scenic River study: U.S. Department of Interior, $119 \mathrm{p}$.

Bureau of Outdoor Recreation, 1976b, Final environmental impact statement, proposed Obed National Wild and Scenic River, Tennessee: U.S. Department of the Interior, $384 \mathrm{p}$.

Burkett, Virginia, Ritschard, Ronald, McNulty, Steven, O'Brien, J.J., Abt, Robert, Jones, James, Hatch, Upton, Murray, Brian, Jagtap, Shrikant, and Cruise, Jim, 2001, Potential consequences of climate variability and change for the southeastern United States, chap. 5 of National Assessment Synthesis Team, U.S. Global Change Research Program, Climate change impacts on the United States - The potential consequences of climate variability and change-Foundation: Cambridge, UK, Cambridge University Press, p. 137-164.
Center for Business and Economic Research, 2014, Population of the United States, Tennessee and Tennessee counties by decennial census years-1790 to 1990: Knoxville, Tennessee, Center for Business and Economic Research, College of Business Administration, University of Tennessee, accessed April 9, 2014, at http://cber. bus.utk.edu/census/1790pop.xls.

Douglas, E.M., Vogel, R.M., and Kroll, C.N., 2000, Trends in floods and low flows in the United States-Impact of spatial correlation: Journal of Hydrology, v. 240, p. 90-105.

Easterling, D.R., Evans, J.L., Groisman, P.Y., Karl, T.R., Kunkel, K.E., and Ambenje, P., 2000, Observed variability and trends in extreme climate events-A brief review: Bulletin of the American Meteorological Society, v. 81, no. 3, p. 417-426.

Evenson, E.J., Orndorff, R.C., Blome, C.D., Böhlke, J.K., Hershberger, P.K., Langenheim, V.E., McCabe, G.J., Morlock, S.E., Reeves, H.W., Verdin, J.P., Weyers, H.S., and Wood, T.M., 2013, U.S. Geological Survey water science strategy_-Observing, understanding, predicting, and delivering water science to the Nation: U.S. Geological Survey Circular 1383-G, 49 p.

Forester, D.E., Mayr, M., Yeager, B.L., and Gardner, K., 1998, Obed Wild and Scenic River water resources management plan: Tennessee Valley Authority, 199 p.

Gaydos, M.W., and others, 1982, Hydrology of Area 19, Eastern Coal Province, Tennessee: U.S. Geological Survey Water-Resources Investigations/Open-File Report 81-901, 75 p.

Goodfred, D.W., 2006, Characterization of benthic macroinvertebrate communities within the Emory River Watershed, Tennessee: Cookeville, Tennessee, Tennessee Technological University, M.S. thesis, $225 \mathrm{p}$.

Goodwin, W.A., 1981, Compilation of small dams in Tennessee: Cookeville, Tennessee, Tennessee Technological University, M.S. thesis [variously paged].

Gore, J.A., Hughes, J.D., Jr., and Swartley, W.A., 1982, A survey of benthic macroinvertebrates of streams of coal surface mining areas of the Cumberland Plateau in Tennessee-Final report: Cookeville, Tennessee, Tennessee Cooperative Fishery Research Unit, Tennessee Technological University, 2 v. [variously paged].

Gottfried, P.K., Bales, J.D., and Precious, T.W., 1984, The influence of coal surface mining on the aquatic environment of the Cumberland Plateau: Washington, D.C., U.S. Environmental Protection Agency, EPA-600/7-84043, 189 p.

Griffith, G.E., Omernik, J.M., and Azevedo, S., 1997, Ecoregions of Tennessee: Corvallis, Oregon, NHREEL, Western Ecological Division, U.S. Environmental Protection Agency, EPA/600/R-97/022, 51 p.

Groisman, P.Y., and Easterling, D.R., 1994, Variability and trends of total precipitation and snowfall over the United States and Canada: Journal of Climatology, v. 7, no. 1, p. 184-205. 
Groisman, P.Y., Knight, R.W., and Karl, T.R., 2001, Heavy precipitation and high streamflow in the contiguous United States-Trends in the 20th century: Bulletin of the American Meteorological Society, v. 82, no. 2, p. 219-246.

Hardeman, W.D., 1966, Geologic map of Tennessee, EastCentral Sheet: Tennessee Division of Geology, 1:250,000.

Hutson, S.S., 1999, Public water-supply systems and associated water use in Tennessee, 1995: U.S. Geological Survey Water-Resources Investigations Report 99-4052, $91 \mathrm{p}$.

Hutson, S.S., and Morris, A.J., 1992, Public water-supply systems and water use in Tennessee, 1988: U.S. Geological Survey Water-Resources Investigations Report 91-4195, $74 \mathrm{p}$.

Johnson, R.C., and Luther, E.T., 1972, Strippable coal in the northern Cumberland Plateau area of Tennessee: Tennessee Division of Geology Report of Investigations No. 34, 41 p., 1 pl.

Karl, T.R., and Knight, R.W., 1998, Secular trends of precipitation amount, frequency, and intensity in the USA: Bulletin of the American Meteorological Society, v. 79, no. 2, p. 231-241.

Karl, T.R., Knight, R.W., Easterling, D.R., and Quayle, R.G., 1996, Indices of climate change for the United States:

Bulletin of the American Meteorological Society, v. 77, no. 2, p. 279-292.

Keith, A., 1897, Wartburg folio, Tennessee: Geologic atlas of the United States, folio 4 p., 4 pls.

Law, G.S., Tasker, G.D., and Ladd, D.E., 2009, Streamflowcharacteristic estimation methods for unregulated streams of Tennessee: U.S. Geological Survey Scientific Investigations Report 2009-5159, 212 p., 1 pl.

Lettenmaier, D.P., Wood, E.F., and Wallis, J.R., 1994, Hydro-climatological trends in the continental United States, 1948-88: Journal of Climatology, v. 7, no. 4, p. 586-607.

Lins, H.F., 2005, Streamflow trends in the United States: U.S. Geological Survey Fact Sheet 2005-3017, 3 p.

Lins, H.F., and Slack, J.R., 1999, Streamflow trends in the United States: Geophysical Research Letters, v. 26, no. 2, p. 227-230.

Luther, E.T., 1959, The coal reserves of Tennessee: Tennessee Division of Geology Bulletin 63, 294 p.

McCabe, G.J., and Wolock, D.M., 2002, A step increase in streamflow in the conterminous United States: Geophysical Research Letters, v. 29, no. 24, p. 2185-2189.

Milici, R.C., 1968, The physiography of Sequatchie Valley and adjacent portions of the Cumberland Plateau, Tennessee: Tennessee Division of Geology Report of Investigations No. 22 reprinted from Southeastern Geology, v. 8 , no. 4, p. 179-193.

Minear, R.A., and Tschantz, B.A., 1976, The effect of coal surface mining on the water quality of mountain drainage basin streams: Journal of the Water Pollution Control Federation, v. 48, no. 11, p. 2549-2569.
National Climatic Data Center, 2014, Data tools-Find a station: National Oceanic and Atmospheric Administration, accessed May 9, 2014, at http://www.ncdc.noaa. gov/cdo-web/datatools/findstation.

National Park Service, 1978, Addendum to the final environmental impact statement, Obed Wild and Scenic River, Tennessee: National Park Service, Denver Service Center, $59 \mathrm{p}$.

National Park Service, 1993, Resource Management Plan, Southeast Region-Obed Wild and Scenic River: National Park Service Denver Service Center, 1 v. [variously paged].

National Park Service, 1995, Obed Wild and Scenic RiverGeneral Management Plan, Development Concept Plan, Environmental Impact Statement: National Park Service Denver Service Center, $161 \mathrm{p}$.

National Park Service, 1999, Baseline water quality data inventory and analysis - Obed Wild and Scenic River: National Park Service Technical Report NPS/NRWRD/ NRTR-98/200, 727 p., accessed November 4, 2010, at http://www.nature.nps.gov/water/horizon.cfm.

National Park Service, 2004, Obed Wild and Scenic River inventory and conversion of surface-water impoundments: prepared by University of Tennessee, Chattanooga, 6 p., 2 CDs.

Pennington, W., and Estes, R.D., 1980, Benthic populations of thirty three stream locations draining coal reserves of Tennessee-Final report: Cookeville, Tennessee, Tennessee Cooperative Fishery Research Unit, Tennessee Technological University [variously paged].

Pringle, C.M., 2000, Threats to U.S. public lands from cumulative hydrologic alterations outside of their boundaries: Ecological Applications, v. 10, no. 4, p. 971-989.

Robinson, J.A., and Brooks, J.M., 2010, Public water-supply systems and associated water use in Tennessee, 2005: U.S. Geological Survey Open-File Report 2010-1226, $100 \mathrm{p}$.

Russ, W.T., II, 2006, Current distribution and seasonal habitat use of the threatened spotfin chub in the Emory River Watershed: Cookeville, Tennessee, Tennessee Technological University, M.S. thesis, $163 \mathrm{p}$.

Smith, S.V., Renwick, W.H., Bartley, J.D., and Buddemeier, R.W., 2002, Distribution and significance of small, artificial water bodies across the United States landscape: Science of the Total Environment: v. 299, no. 1-3, p. 21-36, accessed May 7, 2014, at http://dx.doi. org/10.1016/S0048-9697(02)00222-X.

Stearns, R.G., 1954, The Cumberland Plateau overthrust and geology of the Crab Orchard Mountains area, Tennessee: Tennessee Division of Geology Bulletin 60, $47 \mathrm{p}$.

Tennessee Valley Authority, 1954, Engineering data for TVA water control projects: Technical Monograph No. 55, v. 1,32 chap.

Tennessee Valley Authority, 1958, The occurrence of drought in the Tennessee Valley: Report No. T 58-2 AE, 58 p. 


\section{Hydrologic Data for the Obed River Watershed, Tennessee}

Tennessee Valley Authority, 1960, Supplemental flood histories for Emory \& Obed Rivers and Clear \& Daddy Creeks, Nemo Project: Report No. 0-6082, 100 p., 9 pl.

Tennessee Valley Authority, 1970, Drainage areas for streams in Tennessee River Basin: Report No. 0-5829-R-2, $116 \mathrm{p}$.

U.S. Army Corps of Engineers, 1930, House Document 328, 71st Congress, 2nd Session, 734 p., 199 pl.

U.S. Army Corps of Engineers, 1998, Cumberland County regional water supply: Preliminary Engineering Report [variously paged].

U.S. Geological Survey, 1913, Topographic quadrangle Crossville edition of Nov. 1912, scale: 1/62,500, 20-foot contour interval, 1 sheet.

Webbers, A., 2003, Public water-supply systems and associated water use in Tennessee, 2000: U.S. Geological Survey Water-Resources Investigations Report 03-4264, $90 \mathrm{p}$.

Wilson, C.W., Jr., Jewell, J.W., and Luther, E.T., 1956, Pennsylvanian geology of the Cumberland Plateau: Tennessee Division of Geology Folio, $21 \mathrm{p}$.

Wilson, J.M., 1965, Ground water resources and geology of Cumberland County, Tennessee: Tennessee Division of Water Resources, $56 \mathrm{p}$.

Wolfe, W.J., Evans, J.P., McCarthy, S., Gain, W.S., and Bryan, B.A., 2003, Tree-regeneration and mortality patterns and hydrologic change in a forested karst wetlandSinking Pond, Arnold Air Force Base, Tennessee: U.S. Geological Survey Water-Resources Investigations Report, $53 \mathrm{p}$.

Wolfe, W.J., Fitch, K.C., and Ladd, D.E., 2007, Alluvial bars of the Obed Wild and Scenic River, Tennessee: U.S. Geological Survey Scientific Investigations Map 2007-2972, 1 sheet.

For additional information regarding this publication, contact:

Director

USGS Tennessee Water Science Center

640 Grassmere Park, Suite 100

Nashville, TN 37211

Or visit the USGS Tennessee Water Science Center Web site at: http://tn.water.usgs.gov

Edited and prepared by: USGS Science Publishing Network Raleigh Publishing Service Center 
Appendix 1. Synoptic data for the Obed River watershed, Tennessee, 2003-2005.

[See table 5 for site descriptions and locations; Q, discharge, in cubic feet per second; (D), month and day of observation; K, specific conductance, in microsiemens per centimeter at 25 degrees Celsius; T, water temperature, in degrees Celsius; -, not observed]

\begin{tabular}{|c|c|c|c|c|c|c|c|c|c|c|c|c|}
\hline \multirow{4}{*}{$\begin{array}{l}\text { Site no. } \\
\text { (from } \\
\text { figure 3) }\end{array}$} & \multicolumn{12}{|c|}{ Date and observation } \\
\hline & \multicolumn{12}{|c|}{ High baseflow } \\
\hline & \multicolumn{3}{|c|}{$7 / 14-16 / 2003$} & \multicolumn{3}{|c|}{$5 / 10-12 / 2004$} & \multicolumn{3}{|c|}{ 8/9-10/2004 } & \multicolumn{3}{|c|}{$6 / 6-7 / 2005$} \\
\hline & $\mathbf{O}$ (D) & $\mathbf{K}$ & $\mathbf{T}$ & $\mathbf{0}$ (D) & $\mathbf{K}$ & $\mathbf{T}$ & $\mathbf{0}$ (D) & $\mathbf{K}$ & $\mathbf{T}$ & $\mathbf{0}$ (D) & $\mathbf{K}$ & $\mathbf{T}$ \\
\hline \multicolumn{13}{|c|}{ Obed River watershed synoptic sites } \\
\hline 1 & $0.87(7 / 15)$ & 66 & 21.9 & - & - & - & $1.1(8 / 9)$ & 46 & 18.8 & - & - & - \\
\hline 2 & $0.26(7 / 15)$ & 73 & 17 & - & - & - & - & - & - & - & - & - \\
\hline 3 & $0.38(7 / 15)$ & 64 & 25.3 & - & - & - & 0.02 & - & - & - & - & - \\
\hline 4 & & - & - & $5.4(5 / 12)$ & 43 & 15.6 & $1.2(8 / 9)$ & 47 & 19.1 & - & - & - \\
\hline 5 & $1.93(7 / 14)$ & 64 & 12.7 & $6.4(5 / 11)$ & 51 & 17.4 & $1.9(8 / 10)$ & 61 & 16.9 & - & - & - \\
\hline 6 & $4.4(7 / 14)$ & 80 & 21.1 & $9.4(5 / 11)$ & 59 & 16.5 & $4.2(8 / 9)$ & 75 & 18.8 & - & - & - \\
\hline 7 & $1.2(7 / 15)$ & 114 & 16.7 & $0.83(5 / 11)$ & 74 & 18.1 & $0.29(8 / 9)$ & 107 & 18.6 & - & - & - \\
\hline 8 & $22.1(7 / 15)$ & 32 & 18.3 & $7.7(5 / 10)$ & 30 & 16.3 & $2.9(8 / 9)$ & 34 & 16.7 & $2.4(6 / 6)$ & 32 & 18.4 \\
\hline 9 & $23.4(7 / 15)$ & 49 & 20.4 & $17.8(5 / 10)$ & 30 & 17.5 & $7.5(8 / 9)$ & 38 & 17.3 & $5.2(6 / 6)$ & 35 & 19 \\
\hline 10 & $24.4(7 / 15)$ & 35 & 20.4 & $19.3(5 / 10)$ & 32 & 17.8 & - & - & - & - & - & - \\
\hline 11 & $22.4(7 / 15)$ & 25 & 18.1 & $4.8(5 / 10)$ & 27 & 16.6 & $2(8 / 9)$ & 31 & 17.7 & $1.3(6 / 6)$ & 32 & 20 \\
\hline 12 & $2.3(7 / 14)$ & 162 & 21.4 & $5.5(5 / 11)$ & 141 & 18.3 & $1.4(8 / 10)$ & 191 & 20.5 & $2.2(6 / 7)$ & 220 & 19.4 \\
\hline 13 & $2.4(7 / 14)$ & 68 & 13.6 & $3.5(5 / 11)$ & 69 & 18.2 & $0.78(8 / 10)$ & 91 & 18.9 & - & - & - \\
\hline 14 & $3.3(7 / 14)$ & 66 & 13 & - & - & - & $0.76(8 / 10)$ & 73 & 18.3 & $3.7(6 / 7)$ & 63 & 19.6 \\
\hline 15 & $1.1(7 / 16)$ & 32 & 20 & $3.2(5 / 10)$ & 24 & 14.9 & $0.21(8 / 9)$ & 31 & 16.3 & $1.2(6 / 6)$ & 25 & 19.3 \\
\hline 16 & $0.73(7 / 16)$ & 26 & 19.6 & $3.9(5 / 10)$ & 24 & 14.3 & $0.8(8 / 9)$ & 30 & 16.5 & $1(6 / 6)$ & 23 & 17.7 \\
\hline 17 & $3.7(7 / 16)$ & 83 & 23 & $8.4(5 / 12)$ & 56 & 17.3 & $0.74(8 / 10)$ & - & - & $3(6 / 7)$ & 62 & 19 \\
\hline 18 & $2.2(7 / 14)$ & 43 & 20.1 & $1.5(5 / 11)$ & 41 & 17.2 & $0.57(8 / 10)$ & 54 & 18.2 & $0.57(6 / 6)$ & - & - \\
\hline 19 & $1.2(7 / 14)$ & 30 & 21.5 & $1.4(5 / 11)$ & 28 & 16.7 & $0.22(8 / 10)$ & 33 & 18 & $0.26(6 / 6)$ & - & - \\
\hline 20 & $4.1(7 / 14)$ & 38 & 21 & $4(5 / 11)$ & 36 & 17.9 & $1.4(8 / 10)$ & 48 & 19.5 & $1.1(6 / 6)$ & - & - \\
\hline 21 & $1.5(7 / 14)$ & 66 & 21.3 & $2.4(5 / 11)$ & 50 & 17.7 & $1(8 / 10)$ & 66 & 18.9 & $0.57(6 / 6)$ & - & - \\
\hline 22 & $4(7 / 14)$ & 80 & 23.7 & $6.5(5 / 11)$ & 63 & 19.5 & $1.8(8 / 10)$ & 74 & 20.9 & $1.4(6 / 6)$ & - & - \\
\hline 23 & $4.5(7 / 14)$ & 75 & 23.2 & $3.3(5 / 11)$ & 76 & 19.5 & $0.77(8 / 10)$ & 88 & 22.4 & $0.48(6 / 6)$ & - & - \\
\hline 24 & $7.5(7 / 15)$ & 109 & 22.5 & $12.2(5 / 11)$ & 106 & 18.2 & $2.6(8 / 10)$ & 143 & 21.6 & $2.6(6 / 7)$ & - & - \\
\hline 25 & $1.2(7 / 15)$ & 100 & 22 & $5.1(5 / 11)$ & 97 & 18.1 & $0.72(8 / 10)$ & 106 & 19.5 & $1.8(6 / 7)$ & - & - \\
\hline 26 & $2.3(7 / 15)$ & 109 & 21.1 & $4.1(5 / 11)$ & 87 & 17.4 & $0.3(8 / 10)$ & 132 & 18.3 & $0.73(6 / 7)$ & - & - \\
\hline 27 & $10.4(7 / 15)$ & 54 & 19.8 & $5.3(5 / 11)$ & 251 & 15.3 & $1.1(8 / 9)$ & 148 & 18.8 & $1.5(6 / 7)$ & 184 & 18.7 \\
\hline \multicolumn{13}{|c|}{ Obed River watershed index sites } \\
\hline \multirow[t]{3}{*}{28} & $59(7 / 14)$ & - & - & $72(5 / 10)$ & - & - & $26(8 / 9)$ & - & - & $27(6 / 6)$ & - & - \\
\hline & $47(7 / 15)$ & - & - & $70(5 / 11)$ & - & - & $21(8 / 10)$ & - & - & $25(6 / 7)$ & - & - \\
\hline & $38(7 / 16)$ & - & - & $62(5 / 12)$ & - & - & - & - & - & - & - & - \\
\hline \multirow[t]{3}{*}{29} & $252(7 / 14)$ & - & - & $84(5 / 10)$ & - & - & $36(8 / 9)$ & - & - & $36(6 / 6)$ & - & - \\
\hline & $139(7 / 15)$ & - & - & $104(5 / 11)$ & - & - & $30(8 / 10)$ & - & - & $62(6 / 7)$ & - & - \\
\hline & $98(7 / 16)$ & - & - & $106(5 / 12)$ & - & - & - & - & - & - & - & - \\
\hline \multirow[t]{3}{*}{30} & $420(7 / 14)$ & - & - & $306(5 / 10)$ & - & - & $90(8 / 9)$ & - & - & $137(6 / 6)$ & - & - \\
\hline & $250(7 / 15)$ & - & - & $311(5 / 11)$ & - & - & $71(8 / 10)$ & - & - & $119(6 / 7)$ & - & - \\
\hline & $179(7 / 16)$ & - & - & $315(5 / 12)$ & - & - & - & - & - & - & - & - \\
\hline
\end{tabular}


Appendix 1. Synoptic data for the Obed River watershed, Tennessee, 2003-2005.-Continued

[See table 5 for site descriptions and locations; Q, discharge, in cubic feet per second; (D), month and day of observation; $\mathrm{K}$, specific conductance, in microsiemens per centimeter at 25 degrees Celsius; $\mathrm{T}$, water temperature, in degrees Celsius; ,- not observed]

\begin{tabular}{|c|c|c|c|c|c|c|c|c|c|}
\hline \multirow{4}{*}{$\begin{array}{l}\text { Site no. } \\
\text { (from } \\
\text { figure 3) }\end{array}$} & \multicolumn{9}{|c|}{ Date and observation } \\
\hline & \multicolumn{9}{|c|}{ Low baseflow } \\
\hline & \multicolumn{3}{|c|}{$6 / 22-23 / 2005$} & \multicolumn{3}{|c|}{ 9/12-13/2005 } & \multicolumn{3}{|c|}{$11 / 1 / 2005,11 / 2 / 2005,11 / 4 / 2005$} \\
\hline & $\mathbf{O}(\mathrm{D})$ & $\mathbf{K}$ & $\mathbf{T}$ & $\mathbf{Q}(\mathrm{D})$ & $\mathbf{K}$ & $T$ & $\mathbf{0}(\mathrm{D})$ & $\mathbf{K}$ & $T$ \\
\hline \multicolumn{10}{|c|}{ Obed River watershed synoptic sites } \\
\hline 1 & - & - & - & - & - & - & - & - & - \\
\hline 2 & - & - & - & - & - & - & - & - & - \\
\hline 3 & $0(6 / 23)$ & - & - & - & - & - & - & - & - \\
\hline 4 & $0.54(6 / 23)$ & 50 & 21.8 & - & - & - & - & - & - \\
\hline 5 & $1(6 / 23)$ & - & - & $0.1(9 / 13)$ & 99 & 20.3 & $0.93(11 / 2)$ & 94 & 10.9 \\
\hline 6 & $2.5(6 / 23)$ & 75 & 20.2 & $0.5(9 / 13)$ & 97 & 18.9 & $0.46(11 / 2)$ & 107 & 11.3 \\
\hline 7 & $0.02(6 / 23)$ & 144 & 18.1 & $0.03(9 / 13)$ & - & - & $0.03(11 / 2)$ & 173 & 10.2 \\
\hline 8 & $0.35(6 / 22)$ & 34 & 18.4 & - & - & - & - & - & - \\
\hline 9 & $1.2(6 / 22)$ & 41 & 19.2 & $0.14(9 / 12)$ & 42 & 19.5 & $0.12(11 / 1)$ & 84 & 7.2 \\
\hline 10 & - & - & - & - & - & - & - & - & - \\
\hline 11 & $0.3(6 / 22)$ & 38 & 19.6 & $0.09(9 / 12)$ & 52 & 19.8 & $0.02(11 / 1)$ & 69 & 8.2 \\
\hline 12 & $1.2(6 / 23)$ & - & - & $0.84(9 / 13)$ & 186 & 18.5 & $0.48(11 / 2)$ & 369 & 11.8 \\
\hline 13 & $0.14(6 / 23)$ & 118 & 19 & $0.04(9 / 13)$ & 209 & 19.1 & $0.04(11 / 2)$ & 177 & 10.8 \\
\hline 14 & $0.39(6 / 23)$ & 70 & 21.2 & - & - & - & $0.02(11 / 2)$ & 144 & 12.8 \\
\hline 15 & $0.26(6 / 22)$ & 30 & 19.1 & $0.07(9 / 12)$ & 46 & 19.7 & $0.04(11 / 1)$ & 52 & 9.1 \\
\hline 16 & $0.29(6 / 22)$ & 26 & 17.4 & $0.001(9 / 12)$ & - & - & $0.001(11 / 1)$ & - & - \\
\hline 17 & $1.9(6 / 22)$ & 65 & 19.3 & $1.1(9 / 12)$ & 79 & 18.8 & $0.89(11 / 1)$ & 88 & 9.4 \\
\hline 18 & $0.13(6 / 22)$ & - & - & $0.02(9 / 13)$ & - & - & $0.06(11 / 4)$ & 62 & 9.1 \\
\hline 19 & $0.01(6 / 22)$ & - & - & $0.01(9 / 13)$ & - & - & $0.06(11 / 4)$ & 40 & 10.2 \\
\hline 20 & $0.39(6 / 22)$ & - & - & $0.04(9 / 13)$ & - & - & $0.04(11 / 4)$ & 59 & 10.9 \\
\hline 21 & $0.11(6 / 22)$ & - & - & $0.04(9 / 13)$ & - & - & $0.18(11 / 4)$ & 74 & 9.7 \\
\hline 22 & $0.74(6 / 22)$ & - & - & $0.59(9 / 13)$ & - & - & $0.73(11 / 4)$ & 92 & 10.4 \\
\hline 23 & $0.32(6 / 22)$ & - & - & $0.22(9 / 13)$ & - & - & $0.15(11 / 4)$ & 111 & 10.5 \\
\hline 24 & $1.1(6 / 22)$ & - & - & $0.46(9 / 13)$ & - & - & - & - & - \\
\hline 25 & $0.27(6 / 23)$ & - & - & $0.26(9 / 13)$ & 83 & 19.1 & $0.14(11 / 1)$ & 124 & 9.7 \\
\hline 26 & $0.22(6 / 23)$ & - & - & $0.2(9 / 13)$ & 139 & 18.2 & $0.14(11 / 2)$ & 140 & 7.8 \\
\hline 27 & $0.78(6 / 23)$ & - & - & $1.1(9 / 13)$ & - & - & $0.14(11 / 2)$ & 227 & 8.6 \\
\hline \multicolumn{10}{|c|}{ Obed River watershed index sites } \\
\hline \multirow[t]{3}{*}{28} & $11(6 / 22)$ & - & - & $11(9 / 12)$ & - & - & $5.7(11 / 1)$ & - & - \\
\hline & $9.9(6 / 23)$ & - & - & $9.4(9 / 13)$ & - & - & $5.4(11 / 2)$ & - & - \\
\hline & - & - & - & - & - & - & $4.8(11 / 4)$ & - & - \\
\hline \multirow[t]{3}{*}{29} & $14(6 / 22)$ & - & - & $4(9 / 12)$ & - & - & $1.6(11 / 1)$ & - & - \\
\hline & $13(6 / 23)$ & - & - & $3.4(9 / 13)$ & - & - & $1.7(11 / 2)$ & - & - \\
\hline & - & - & - & - & - & - & $1.4(11 / 4)$ & - & - \\
\hline \multirow[t]{3}{*}{30} & $45(6 / 22)$ & - & - & $22(9 / 12)$ & - & - & $12(11 / 1)$ & - & - \\
\hline & $40(6 / 23)$ & - & - & $21(9 / 13)$ & - & - & $11(11 / 2)$ & - & - \\
\hline & - & - & - & - & - & - & $11(11 / 4)$ & - & - \\
\hline
\end{tabular}





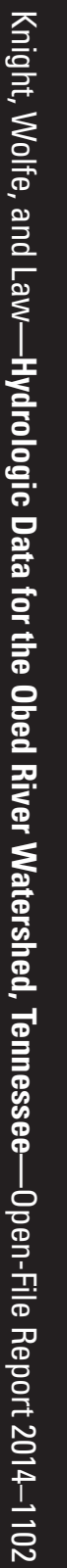

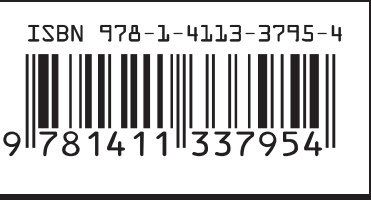

3 Printed on recycled paper

ISSN 0196-1497 (print)

ISSN 2331-1258 (online)

http://dx.doi.org/10.3133/ofr20141102 